\title{
NO HAY EJERCICIO DEL DERECHO FUNDAMENTAL DE ACCIÓN EN EL PROCESO PENAL. SENTENCIA DEL TRIBUNAL CONSTITUCIONAL QUE DECLARÓ INAPLICABLE EL ARTÍCULO 230 DEL CÓDIGO PROCESAL PENAL
}

\author{
Comentario de Andrés Bordali Salamanca
}

Santiago, diecinueve de agosto de dos mil ocho.

VISTOS:

Con fecha 10 de julio de 2007, Patricio Rodrigo Meneses Farías ha formulado una acción de inaplicabilidad por inconstitucionalidad del artículo 230, inciso primero, del Código Procesal Penal, que incide en la causa RIT N 179-2005, RUC No 0510001570-8, que se tramita ante el Juzgado de Garantía de San Fernando, la que se refiere a una querella criminal interpuesta por el requirente por el delito de falsificación de instrumento privado.

La norma impugnada dispone:

"Artículo 230. Oportunidad de la formalización de la investigación. El fiscal podrá formalizar la investigación cuando considerare oportuno formalizar el procedimiento por medio de la intervención judicial.

Cuando el fiscal debiere requerir la intervención judicial para la práctica de determinadas diligencias de investigación, la recepción anticipada de prueba o la resolución sobre medidas cautelares, estará obligado a formalizar la investigación, a menos que lo bubiere realizado previamente. Exceptúanse los casos expresamente señalados en la ley".

Con fecha 12 de julio de 2007, la Segunda Sala de esta Magistratura declaró admisible el requerimiento, pasando los autos al Pleno para su substanciación.

Con fecha 16 de agosto del mismo año, el Ministerio Público evacuó el traslado conferido.

I. Antecedentes tenidos a la vista:

La causa que motiva esta acción está basada en la querella criminal interpuesta el 2 de febrero de 2005, por el requirente Patricio Meneses Farías, por el delito de falsificación de instrumento privado contemplado en el artículo 197, inciso segundo, del Código Penal, la cual fue declarada admisible por el Juez de Garantía de San Fernando. Posteriormente, el 7 de junio de 2005, el Fiscal Adjunto de la Fiscalía de San Fernando solicitó el sobreseimiento definitivo de la causa no formalizada, ya que se habría cerrado 
la investigación sin reunir los antecedentes necesarios para perseverar en la persecución penal. El querellante, a su vez, el 24 de junio de 2005, expresó que la fiscalía no habría efectuado la investigación pertinente, dejándolo en indefensión, por lo que solicitó un nuevo plazo para agotar diligencias. Con fecha 29 de junio de 2005 se lleva a cabo la audiencia de sobreseimiento en la cual el Ministerio Público insistió en que, dados los antecedentes de la investigación, cabía el sobreseimiento definitivo.

Ante tal situación, el tribunal resolvió fijar una nueva audiencia para discutir el sobreseimiento y para debatir las demás acciones que quedaban pendientes, la que se realizó el día 12 de agosto de 2005 y, a resultas de lo allí expuesto y confrontado, el tribunal resolvió, en primer lugar, no dar lugar a la ejecución de ciertas diligencias de investigación solicitadas, desestimando la reapertura de la investigación; en segundo lugar, ya que del mérito de los antecedentes no se desprendía que existieran datos que justificaran la existencia de algún delito, resolvió acoger la petición del Ministerio Público y sobreseer definitivamente la causa y, finalmente, condenó en costas a la querellante solidariamente con su abogado defensor. Tal resolución del Juez de Garantía de San Fernando fue apelada por el querellante con fecha 17 de agosto de 2005.

La Corte de Apelaciones de Rancagua, con fecha 9 de septiembre de 2005, conociendo de la apelación, resolvió: hacer lugar a la solicitud de diligencias planteadas por el querellante, ordenado al Ministerio Público reabrir la investigación para practicarlas dentro de 60 días, y rechazó el sobreseimiento definitivo y consecuencialmente la condena en costas, fundado en que no procede solicitarse el sobreseimiento en un proceso que no ha sido formalizado.

A raíz de la resolución de la Corte de Apelaciones de Rancagua, con fecha $1^{\circ}$ de julio de 2006 el querellante solicitó al Juzgado de Garantía de San Fernando audiencia para la formalización de cargos por parte del Ministerio Público.

En la audiencia de 16 de noviembre, el Juez de Garantía de San Fernando señaló que "si el Ministerio Público no encuentra en este momento antecedentes suficientes para formalizar por delito alguno, las cosas en ese estado deben permanecer", añadiendo que "la acción no puede estar restringida a lo que señala el querellante (...) pero en definitiva el motor de la investigación penal la tiene el Ministerio Público", resolución que fue apelada por el querellante el 21 de noviembre de 2006. La Corte de Apelaciones de Rancagua en sentencia de 4 de enero de 2007 confirmó esta vez la resolución dictada por el Juez de Garantía de San Fernando.

II. Fundamentos de la inaplicabilidad solicitada:

a. La disposición impugnada configura indebidamente una atribución exclusiva del Ministerio Público.

Expresa el requirente que la norma recurrida va en contra de texto expreso de la Constitución, puesto que da a entender que la facultad de formalizar sería discrecional del fiscal, porque supone que dicha atribución de formalizar es exclusiva y excluyente. De esta forma, el Ministerio Público entendería que sólo él puede formalizar, cuando lo estime oportuno y a su mero arbitrio. 
Sobre esta materia, el Ministerio Público indica que el sistema de persecución criminal se basa, entre otros principios, en el de oficialidad, por el cual el Estado puede y debe perseguir los delitos de oficio, sin consideración a la voluntad del ofendido. Añade que, vinculado al principio de persecución, se encuentra el régimen a que se somete la acción penal, pudiendo ésta ser pública, pública previa instancia particular o privada, y el principio de oficialidad se encuentra presente con mayor énfasis en las dos primeras. En las acciones penales públicas priman el interés público y la intervención estatal a través del Ministerio Público en el nuevo sistema. Esto tiene que ver con la disponibilidad de la persecución, que en estas acciones públicas está en manos del Estado.

Expresa además el Ministerio Público que, respecto al ejercicio de la acción penal, debe entenderse, en primer lugar, que dicho ejercicio implica acusar, lo que encuentra su apoyo en el artículo 83 de la Constitución, disposición que distingue entre la investigación, entregada exclusivamente al Ministerio Público, y el ejercicio de la acción penal pública, que se hará "en su caso" por ese organismo. Además, sostiene que debe entenderse también incluida la facultad de promover la persecución o de dar inicio al proceso penal.

b. El artículo $19 \mathrm{~N}^{\circ} 3$ inciso quinto, de la Constitución que consagra el debido proceso y el justo y racional procedimiento.

El requirente señala que no aparece racional ni justo que la víctima de un delito no pueda ejercer la acción penal que le otorga la Constitución sin la aquiescencia del Ministerio Público, quien a su arbitrio o capricho puede determinar si formaliza o no, prescindiendo de si existe mérito para hacerlo. Por la vía de negarse a formalizar, deja en la impunidad hechos delictuales en perjuicio de la víctima que dedujo querella ante el tribunal competente.

El Ministerio Público al respecto expresa que esta argumentación no tiene relación con la norma impugnada, dado que el ejercicio de la acción penal es la facultad de promover el procedimiento, y ello está asegurado por la querella; añade que ese ejercicio, entendido como acusación, requiere que el órgano estatal a cargo de la investigación estime que cuenta con antecedentes suficientes para llevar al imputado a juicio, lo que es consecuencia del principio de oficialidad. En todo caso, aun sin la aquiescencia del Ministerio Público, el querellante puede acusar y llevar a juicio al imputado en los casos señalados en el artículo 248 del Código Procesal Penal.

c. La vulneración de la igualdad ante la ley.

En esta parte el requirente enuncia la vulneración a esta garantía constitucional por parte del citado inciso primero del artículo 230 del Código Procesal Penal.

El Ministerio Público, por su parte, indica que, respecto al tema de la igualdad, probablemente la invocación del requirente está referida a cierta igualdad entre el acusador fiscal y el ofendido. Sin embargo, la igualdad que reclama el requirente no existe durante la investigación penal, ya que el Ministerio Público y el querellante se ubican en situaciones absolutamente diversas, teniendo el Ministerio Público la dirección exclusiva de la averiguación criminal y una posición predominante en esta etapa del 
proceso penal. Además, la igualdad del artículo $19 \mathrm{~N}^{\circ} 2$ se refiere a aquellas personas que se encuentren en las mismas circunstancias, lo que acá no sucede.

\section{d. El Ministerio Público como legislador.}

El requirente indica que, a raíz de la norma impugnada, el Ministerio Público se transforma en legislador al crear una causal eximente de responsabilidad penal no indicada en la ley, por la vía de negarse a formalizar.

Al respecto, el Ministerio Público señala que la decisión de formalizar o la oportunidad para hacerlo no se puede considerar como acto legislativo, puesto que no es un acto de creación de una ley.

\section{e. Artículo 83 de la Constitución.}

El requirente expresa que si el Ministerio Público es quien puede determinar formalizar o no, termina ejerciendo funciones jurisdiccionales de manera indirecta, violando así la norma constitucional. Siendo una facultad exclusiva y excluyente del Ministerio Público, se impide el ejercicio de la acción penal, ya que sin formalización no puede haber acusación. El artículo 83 de la Constitución señala que el Ministerio Público dirigirá en forma exclusiva la investigación y en caso alguno podrá ejercer funciones jurisdiccionales.

En este capítulo el Ministerio Público expresa que no ha sido una cuestión fundada, pero el requirente al señalar que el Ministerio Público tendría la facultad de decidir qué asuntos se someten a juicio o no, lo que hace, en efecto, es situar a ese organismo fuera del ejercicio jurisdiccional.

\section{La norma cuestionada no es decisiva.}

Señala el Ministerio Público que la norma impugnada no puede ser considerada decisiva en la resolución del asunto, puesto que se refiere a trámites ajenos a la resolución sustantiva del asunto. Además no lo es ya que si se considera que lo reclamado es que la formalización sea resorte exclusivo del Ministerio Público, esto no se desprende del inciso primero del artículo 230 del Código Procesal Penal, sino del concepto de “formalización", contenido en el artículo 229, que no se reprocha en este requerimiento. Formalización es la comunicación que el fiscal efectúa al imputado, en presencia del juez de garantía, de que desarrolla actualmente una investigación en su contra respecto de uno o más delitos determinados, de tal modo que si se declarara inaplicable la norma impugnada, la formalización se conservaría como una actuación propia y exclusiva del fiscal del Ministerio Público, por lo que igualmente aquélla resulta no decisiva.

Indica además el Ministerio Público que si formalizar es comunicar que se desarrolla una investigación, y si esta actividad es dirigida exclusivamente por el Ministerio Público - por mandato constitucional-, se concluye que el Ministerio Público es quien únicamente puede formalizar, como lo señala el artículo 229. Debido a sus efectos, es la misma ley la que ha puesto en manos del fiscal la decisión acerca de cuándo formalizar, conforme lo prescribe el inciso primero del artículo 230. Por lo tanto, la 
norma sólo viene a puntualizar que será el fiscal quien determinará la oportunidad de la formalización.

Añade el Ministerio Público que la facultad de investigar no sólo alcanza a la averiguación de lo que permita acreditar el delito y la participación del imputado, sino que también lo que permita establecer su inocencia, acorde a su deber de objetividad consagrado en la Ley N 19.640, Orgánica Constitucional del Ministerio Público, todo lo cual constituye una diferencia fundamental con el querellante, en relación al ejercicio de la acción penal. Por lo tanto, la expresión "igualmente" contenida en el inciso segundo del artículo 83 de la Constitución no puede significar plena igualdad en el ejercicio de la acción por parte del Ministerio Público y el que pueda hacer el ofendido, por lo que debe entenderse en referencia a las condiciones que la Carta ha impuesto al ejercicio de la acción penal por el acusador fiscal, en la forma prevista por la ley. Expresa que el Código Procesal Penal regula los casos y forma en que el ofendido está facultado para ejercer la acción penal: si se estima que el ejercicio de la acción corresponde al derecho a "promover la persecución" o "incoar" el procedimiento, se llevará a la práctica por medio de la querella. Pero, si se estima que ejercer la acción es "acusar", se podrá llevar adelante siempre que el fiscal decida también acusar, o incluso cuando decida pedir el sobreseimiento o no perseverar, según el artículo 258 del Código, conocido como el forzamiento de la acusación, que permite al querellante acusar y provocar el juicio sin la presencia del Ministerio Público.

La Constitución no asegura al ofendido el ejercicio en todo caso de la acción penal pública, entendido como acusación, pues ha entregado a la ley la determinación de los casos y forma de proceder por el ofendido, y el Código permite avanzar hasta una acusación cada vez que el órgano investigador estime que cuenta con fundamentos para llevar al imputado a juicio, lo que tiene relación con el principio de oficialidad y no pugna con las normas constitucionales. De esta forma no hay incidencia del inciso primero del artículo 230 del Código, que además no puede considerarse contrario al inciso segundo del artículo 83 de la Constitución.

Se ordenó traer los autos en relación y con fecha 15 de noviembre de 2007 se procedió a la vista de la causa, alegando los abogados Saturnino Muñoz Briceño, por el requirente, y José Luis Pérez Calaf por el Ministerio Público.

\section{CONSIDERANDO:}

\section{CONSIDERACIONES GENERALES}

PRIMERO. Que el requerimiento persigue, como lo expresa en su parte petitoria, que se inaplique el inciso primero del artículo 230 del Código Procesal Penal, que se refiere a la oportunidad en que el fiscal podrá formalizar la investigación, ello por cuanto la aplicación del precepto, a su juicio, hace inviable la eficacia del ejercicio de la acción penal por parte del querellante particular, derecho reconocido por el artículo 83 de la Constitución Política, como más adelante se señalará. El precepto impugnado expresa: 
"Artículo 230. Oportunidad de la formalización de la investigación. El fiscal podrá formalizar la investigación cuando considerare oportuno formalizar el procedimiento por medio de la intervención judicial".

No obstante, del contenido del requerimiento y de la respuesta al mismo por el Ministerio Público, se pone en evidencia que el presente conflicto de constitucionalidad nace a partir de y es una consecuencia de la existencia de posiciones opuestas frente a la intervención de la víctima como interviniente o parte del proceso penal, toda vez que el requirente pretende una participación amplia del querellante, en cambio, el Ministerio Público, representado por el Fiscal Nacional, postula su carácter de titular preeminente del ejercicio de la acción penal pública, lo que subordinaría a su quehacer, la participación del ofendido en el proceso penal.

Como presupuesto necesario para la resolución del requerimiento, dichas argumentaciones impulsan a esta Magistratura a razonar a la luz de lo señalado por las partes, no obstante que la sentencia se limitará únicamente a decidir si el precepto impugnado resulta o no inaplicable por vicios de inconstitucionalidad, en el marco del presente control concreto.

SEGUNDO. Que, en este contexto, el actor del presente proceso constitucional afirma que " no es factible que la formalización, que es la llave de inicio del proceso penal, quede entregada de manera exclusiva y excluyente a un organismo todopoderoso como es el Ministerio Público, el cual puede determinar por sí y ante sí, sin ningún control jurisdiccional, cuándo formaliza, al margen de consideraciones de racionalidad y de justicia", concluyendo que, siendo la formalización requisito para que la querella efectivamente se tramite y produzca algún efecto, se violentan las normas constitucionales que sustentan su pretensión.

En lo específico, señala el requirente que se está infringiendo el derecho que le otorga la Constitución al ofendido por el delito para impulsar primero y ser sujeto activo, después, en los procesos penales por acción pública, toda vez que el Fiscal Nacional en su respuesta afirma que la investigación, su duración, si ésta es traspasada al proceso penal, y cuándo se haga ello, es de su competencia exclusiva en virtud del principio de oportunidad, contemplado por la ley vigente, que lo habilitaría para formalizar si y cuando lo considere oportuno.

A su turno, el Ministerio Público señala que, de acuerdo al principio de oficialidad que inspiró la reforma procesal penal, el Estado es quien puede y debe perseguir los delitos de oficio, sin subordinarlo a la voluntad del ofendido.

Dichas posiciones, enfrentadas a la normativa constitucional, conducen a esta Magistratura a formular, por ahora, algunas consideraciones acerca de si el conjunto de actos procesales que constituyen la formalización que se cuestiona, en cuanto aplica lo que en sentido amplio se entiende por principio de oportunidad, son meramente facultativos y discrecionales para el Ministerio Público, de conformidad al precepto que se impugna, o si, por el contrario, deben ejecutarse cuando concurran sus presupuestos procesales habilitantes.

Nos enfrentamos por esta vía a la necesidad de analizar y ponderar si en el ejercicio de esta atribución, en el caso concreto, se cumplen o no los estándares constitucionales 
destinados a dar eficacia al derecho a la tutela judicial efectiva y a la garantía de una investigación racional y justa, establecidos en el artículo 19 número $3^{\circ}$ de la Constitución y antecedente determinante para la aplicación del artículo 230 impugnado en esta causa, teniendo especialmente en cuenta lo dispuesto por el artículo 83 de la misma, en cuanto dispone que el "Ministerio Público dirigirá en forma exclusiva la investigación de los hechos constitutivos de delito, los que determinen la participación punible y los que acrediten la inocencia del imputado y, en su caso, ejercerá la acción penal pública en la forma prevista por la ley" y agrega que "el ofendido por el delito y las demás personas que determine la ley podrán ejercer igualmente la acción penal".

TERCERO. Que, atendido que el Código Procesal Penal no fue objeto de control preventivo de constitucionalidad, es en estas oportunidades cuando el Tribunal Constitucional debe realizarlo, encontrándose limitado por el marco de los casos concretos sometidos a su conocimiento, para lo cual debe confrontar el requerimiento, como un todo, con la preceptiva legal impugnada en el mismo, comprendiendo su ubicación, función y sentido en el contexto del conjunto de normas que componen el nuevo sistema procesal penal, con la normativa constitucional que lo sustenta.

Sin entrar a emitir opinión acerca del mérito de la causa en que incide el requerimiento, resulta necesario destacar, por razones de método y análisis, que las facultades de investigar y luego de formalizar, no pueden ser entendidas como actos discrecionales y aislados, ya que forman parte y constituyen la fase de iniciación del nuevo proceso penal. Por tal motivo, concurriendo los presupuestos procesales que las sustentan, los fiscales tienen el deber de practicarlas.

Cabe agregar que el "deber de formalizar", implícito en las normas constitucionales del Ministerio Público, implica la concreción del derecho que le asiste a toda víctima de un hecho punible a lograr que el Ministerio Público realice, en cumplimiento del mandato constitucional, una investigación racional y justa, derecho fundamental que la Constitución le asegura a toda persona involucrada en un conflicto penal y cuya eficacia implica, como natural efecto, que cumpla con su deber de investigar lo ocurrido en conformidad a los parámetros expresados, dado que es el único órgano que, conforme a la Constitución, ostenta la titularidad y el monopolio de la dirección de la investigación criminal.

Esta materia resulta especialmente relevante, en tanto se mantengan vigentes las disposiciones del Código Procesal Penal que le otorgan privativamente al Ministerio Público la dirección de la investigación y, a continuación, las facultades de investigar y formalizar, sin las cuales no puede haber acusación, ni juicio, ya que dichos actos procesales constituyen presupuestos básicos de la apertura del proceso y de su posterior desarrollo hasta llegar a su solución.

CUARTO. Que, para una acertada inteligencia de la cuestión sometida al conocimiento y resolución de este Tribunal, cabe recordar que la investigación no formalizada comienza a partir de un hecho que el propio Ministerio Público ha calificado como delito. Si lo formaliza, nace el proceso penal; si no lo hace, nunca llegará a la potestad del órgano jurisdiccional, lo que significa, por una parte, subordinar a una decisión 
del persecutor estatal el ejercicio de la jurisdicción y, por la otra, como consecuencia obvia y necesaria, privar a la víctima del derecho que le otorga expresamente la Carta Fundamental a tener un proceso racional y justo en el cual pueda hacer valer sus derechos y lograr su tutela efectiva por medio de una sentencia. En consecuencia, interpretada armónicamente la Constitución después de la modificación del artículo 19 número $3^{\circ}$ por la Ley $\mathrm{N}^{\circ} 19.519$, debe necesariamente concluirse que la investigación está concebida como una vía para llegar a un proceso jurisdiccional, forma prevista por el Constituyente para la solución de los conflictos penales una vez que exista convicción en torno a la existencia del hecho punible, sin perjuicio de que éstos puedan ser objeto de una acusación o terminar por los otros mecanismos establecidos por la ley.

Como corolario de lo anterior, cabe concluir que cualquier razonamiento que conduzca a privar a la víctima de su derecho a ejercer la acción penal, dando así eficacia a su decisión de contar con un proceso jurisdiccional donde se le haga justicia, por causa de decisiones del Ministerio Público, ha de ser descartada, pues subordina el derecho de acceder a los tribunales a las decisiones del persecutor estatal, con lo cual se la priva, de esa forma, del derecho a la acción que le confiere el numeral $3^{\circ}$ del artículo 19 de la Carta Fundamental, en concordancia con el artículo 83 de la misma.

QUINTO. Que de las disposiciones constitucionales invocadas surge nítidamente que "el poder" de investigar del Ministerio Público genera como consecuencia "el deber" de hacerlo, única alternativa procesal para dar eficacia a la función constitucional que se le otorgó.

Es por ello que la Carta Fundamental fue modificada para asegurar la exigibilidad de la investigación, racional y justa, lo que no ocurrirá, si el órgano persecutor puede determinar libremente qué investiga, o cuándo lo hace o no lo hace, decidir de la misma forma si formaliza o no la investigación y cuándo, puesto que con dichas decisiones, según cual sea su determinación, podrá provocar la indefensión de la víctima que no tendrá la investigación racional y justa de los hechos que le garantiza la Constitución y que, como su natural consecuencia, puede impedirle acceder a la formalización, que es el presupuesto necesario para la apertura y prosecución del proceso jurisdiccional.

Lo anterior deberá, posteriormente, armonizarse con el llamado principio de oportunidad, contemplado, lato sensu, entre otros, por los artículos 167 y 170 del Código Procesal Penal.

Es por ello y en este contexto que para continuar este examen concreto de constitucionalidad es menester distinguir con claridad entre el deber de la investigación, su formalización judicial y la oportunidad para hacerlo, actos procesales que el Código Procesal Penal reserva a los representantes del Ministerio Público.

\section{LA ACCIÓN Y EL PROCESO PENAL}

SEXTO. Que con la incorporación del Ministerio Público como operador del sistema procesal penal, la acción, en tanto está destinada, en esta primera fase no jurisdiccional, a lograr la investigación de los hechos, debe necesariamente dirigirse en contra de 
dicho órgano, creándose así una etapa intermedia entre la comisión del hecho punible y el proceso penal, lo que, como se dirá, produce importantes efectos.

Al tratar esta materia, resulta necesario destacar que la Constitución reconoce expresamente el derecho a la acción al ofendido, el que surge como una garantía trascendente para compensar a la víctima de la prohibición y eventual sanción a la autotutela de sus derechos -acción directa-.

Uno de los grandes valores que la Constitución consagra es el acceso al proceso, lato sensu, al expresar que toda sentencia de un órgano que ejerza jurisdicción debe fundarse en un proceso previo legalmente tramitado, correspondiendo al legislador establecer las garantías de un procedimiento e investigación racionales y justos. En este orden de regulaciones procesales, la Carta establece al Ministerio Público como el receptor natural de la noticia de la comisión del hecho punible, que, en consecuencia, en esta fase primaria de la investigación, es el destinatario de la acción por la cual se solicita investigar y posteriormente traspasar el conflicto al órgano jurisdiccional.

En este entorno, el ejercicio de la acción penal, forma ordinaria de impulsar la apertura y formación del proceso, continua siendo el presupuesto primario de su iniciación y, como tal, la primera fase para que éste se tramite legalmente como lo exige la Constitución, lo que debe producir como su efecto natural la apertura del mismo e, incorporándose a él, tiene fundamento constitucional directo, pues constituye un elemento esencial y necesario para que el proceso exista, aun antes de ser calificado, como racional y justo. Es por ello que la ley de procedimiento a que se refiere el artículo 19 en su numeral $3^{\circ}$ debe dictarse para establecer su substanciación, tiene que asegurar el derecho a la acción, ya que si así no fuere, no habría posibilidad de proceso alguno.

Para estos efectos, uno de los grandes cambios en la estructura del proceso penal consiste en que ahora se generan dos fases distintas y sucesivas para la solución de los conflictos penales, ambas impulsadas por medio del ejercicio de la acción procesal, la primera ante el Ministerio Público y la segunda ante el tribunal competente. La primera es pública y en la segunda son sujetos legitimados y activos los mencionados por el artículo 83 de la Constitución, entre los cuales es figura preeminente el Ministerio Público, que sostiene tener el monopolio de su ejercicio.

Lo antes expresado llama a razonar en torno al claro contenido del artículo 83 de la Carta Política, que en el marco de la incorporación y regulación del Ministerio Público señala que éste ejercerá la acción penal pública en la forma prevista por la ley, agregando en su inciso segundo, ya recordado, que "el ofendido por el delito y las demás personas que determine la ley podrán ejercer la acción penal”, estableciendo un estatuto normativo de equilibrio entre su ejercicio por el persecutor estatal y por la víctima.

De lo razonado hasta el momento se desprende que hoy nuestro ordenamiento contempla las siguientes alternativas en torno al ejercicio de la acción en la primera fase de investigación:

a) La comunicación o denuncia de la existencia de un hecho punible al Ministerio Público, acto regulado en cuanto a su ejercicio expresamente por el Código Procesal Penal, lo que en términos procesales implica, preliminarmente, accionar ante el organismo investigador. 
b) El ejercicio de la acción penal pública ante el tribunal competente, que, de acuerdo al mérito de los hechos investigados, es impulsada por su titular principal, el Ministerio Público, ante el Tribunal con competencia penal, que provoca la iniciación de la actividad jurisdiccional, ya sea para solicitar medidas preventivas o para formalizar.

c) La acción penal que el artículo 83, en concordancia con las disposiciones del citado Código, le reconoce a las víctimas ofendidas por el hecho punible y que constituye el fundamento del requerimiento, carece de autonomía, pues depende de un acto de un tercero.

SÉPTIMO. Que ya se ha formado consenso jurisprudencial en torno al concepto, contenido y desarrollo de la función jurisdiccional. En efecto, esta Magistratura, en sentencias Roles $\mathrm{N}^{\text {os. }} 165,198,340,346,472,478,499$ y 616, entre otras, tuvo oportunidad de hacerlo, señalando que la jurisdicción es el poder deber que tienen los tribunales para conocer y resolver, por medio del proceso y con efecto de cosa juzgada, los conflictos de intereses de relevancia jurídica que se promuevan en el orden temporal, dentro del territorio de la República, y en cuya solución les corresponda intervenir.

El poder deber de la jurisdicción se manifiesta, en cuanto a lo primero, en el citado artículo 76, que establece perentoriamente que el ejercicio de la jurisdicción radica en los Tribunales y, en el caso de los conflictos penales, les permite procesar y eventualmente condenar a los imputados a las penas que la ley establece de acuerdo a los delitos de que se trate. No obstante, debe siempre recordarse que la misma disposición agrega que, requerido un tribunal en forma legal y en materias de su competencia, deberá ejercerla a fin de solucionar efectivamente el conflicto sometido a su conocimiento. Es la consagración del deber de la jurisdicción.

OCTAVO. Que, en concordancia con lo expresado acerca de la jurisdicción y sus momentos, cabe reiterar que por la reforma constitucional del año 1997, la investigación penal fue extraída de la competencia de los tribunales y su dirección y ejercicio, le fue entregada por la Carta Básica a los fiscales, como representantes de un organismo autónomo y técnico que denominó Ministerio Público.

En considerandos que más adelante se precisarán, se razonará en torno a las atribuciones que, en el ámbito de este requerimiento, tiene en el marco del nuevo proceso penal.

En otros términos, se norma, como regla general, el traspaso del conflicto penal al proceso jurisdiccional a través del ejercicio de la acción procesal por el Ministerio Público, sin perjuicio que el Código Procesal Penal legalizó el empleo de ciertos mecanismos autocompositivos para ponerle término. 


\section{El DERECHO DE LA VÍCTIMA A LA TUTELA JUDICIAL EFECTIVA}

\section{EN EL SISTEMA CONSTITUCIONAL CHILENO}

NOVENO. Que las Constituciones europeas consagran el derecho fundamental de toda persona a la tutela judicial efectiva de sus intereses y derechos, destacándose especialmente lo dispuesto por la Carta española, en su artículo 24.2. Dicha disposición, por la vía de los procesos de amparo constitucional extraordinario, ha generado una abundante jurisprudencia que, en lo que interesa, permite concluir que los derechos de la víctima y del imputado en el proceso penal deben gozar de garantías efectivas equivalentes y que su custodio es el juez.

El Estado proclama como valor fundamental que los seres humanos "nacen libres e iguales en dignidad y derechos”, además de manifestar que en Chile las personas son iguales ante la ley, sin que existan privilegios de ninguna especie. Es por ello que la Constitución, más allá de las normas citadas de su texto, reconoce de manera expresa el conjunto valórico normativo que configura la tutela judicial efectiva de los derechos e intereses de las personas, declarando también que los derechos fundamentales deben ser respetados y promovidos por todos los órganos del Estado, incluido especialmente el Ministerio Público, según se desprende de los artículos $1^{\circ}, 5^{\circ}, 6^{\circ}$ y 19 , números $2^{\circ}$, $3^{\circ}$ y 26 , de la Carta Fundamental.

En este sentido, este derecho fundamental, que incluye entre sus elementos esenciales el acceso a la jurisdicción, es definido por los especialistas como "aquel que tiene toda persona a obtener tutela efectiva de sus derechos e intereses legitimos ante el juez ordinario predeterminado por la ley y a través de un proceso con todas las garantías, sin dilaciones indebidas y en el que no se produzca indefensión" (Gregorio Cámara Villar, en Francisco Balaguer Callejón y otros, "Derecho Constitucional", tomo II, pág. 215, Ed. Tecnos, Madrid, 2005). Este derecho incluye el libre acceso a la jurisdicción, el derecho a obtener una resolución acerca de la pretensión deducida, el derecho a la ejecución de las resoluciones judiciales, la interdicción de la indefensión y el derecho al debido proceso, con la plena eficacia de todas las garantías que le son propias.

DÉCIMO. Que nuestra Constitución consagra, sin denominarlo así, el invocado derecho a la tutela judicial efectiva, en el inciso primero del artículo 19 , numeral $3^{\circ}$, y en las normas que lo complementan, al reconocerse con fuerza normativa que todas las personas son iguales en el ejercicio de los derechos, lo que comprende, en nuestro medio, su igualdad de posibilidades ante los órganos jurisdiccionales, incluyendo, en primer término, el derecho a la acción, sin el cual quedaría amenazado e incompleto.

En efecto, el primer inciso del numeral $3^{\circ}$ del artículo 19 lo reconoce en forma expresa, correspondiendo su titularidad a la persona como sujeto legitimado para su ejercicio, el que está contemplado en una norma autosuficiente y autoejecutiva.

Como complemento necesario, los incisos siguientes establecen garantías normativas del mismo, consistentes en la legalidad del tribunal y del proceso, además del parámetro de densidad material mínima de dichas normas legales, consistentes en las garantías del racional y justo procedimiento, a lo cual se le sumó la investigación, fijan 
el límite a la autonomía del legislador, a la hora de establecer el marco regulatorio del proceso jurisdiccional, como forma de solución del conflicto y de los actos necesarios para abrirlo, sustanciarlo y cerrarlo.

Debemos reafirmar entonces que el derecho a la tutela judicial efectiva tiene una doble dimensión, por una parte adjetiva, respecto de los otros derechos e intereses, y por la otra, sustantiva, pues es en sí mismo un derecho fundamental autónomo, que tiene por finalidad que las personas accedan al proceso como medio ordinario de resolución de los conflictos jurídicos, lo que resulta un presupuesto mínimo de todo Estado de derecho.

DECIMOPRIMERO. Que en el marco de su reconocimiento constitucional incluye, como única forma de garantizarlo, el acceso efectivo a la jurisdicción, que se manifiesta en la exigibilidad de la apertura y, consecuentemente, de la sustanciación del proceso. A la hora de reconocerlo, deben tenerse en cuenta dos elementos que necesariamente son complementarios e interrelacionados: el derecho a la acción, de configuración constitucional autoejecutiva, y el derecho a la apertura y posterior sustanciación del proceso, cuyo ejercicio será regulado por la determinación legal de las normas del procedimiento y de la investigación, esta última realizada privativa y exclusivamente por el Ministerio Público. Cabe resaltar que dichas normas legales son las que satisfacen los parámetros constitucionales de racionalidad y justicia.

En este sentido, ha de cumplirse con las formalidades, plazos y requisitos establecidos en la legislación procesal dictada en conformidad al mandato constitucional, que es en este caso la preceptiva legal regulatoria que le da eficacia al ejercicio del derecho fundamental a la tutela judicial efectiva.

A este respecto, debe tenerse especialmente presente que al legislador le está vedado establecer condiciones o requisitos que impidan o limiten el libre ejercicio del derecho de acceso a la jurisdicción o lo dejen condicionado a la voluntad de otro de los intervinientes, ya que si así lo hiciere incurre en infracción a la normativa constitucional básica que le da forma al derecho, porque contraviene lo establecido en el numeral $26^{\circ}$ del artículo 19.

Resulta de toda obviedad que este espectro de derechos básicos ha de alcanzar también, e igualmente, a los actos preparatorios de carácter previo al acceso al tribunal competente y, en concreto, a la etapa de investigación prevista en el nuevo proceso penal, más aún si la Carta Fundamental ordena que la investigación resultante deba ser racional y justa.

La negación, o simplemente la excesiva limitación, de lo expresado en los dos párrafos anteriores lleva, necesaria e indefectiblemente, a la frustración de la tutela y a la carencia de la garantía jurisdiccional de todo derecho o interés, lo que es particularmente grave en materia penal. Ello constituye la negación misma del derecho a la tutela judicial efectiva y, como si ello no fuere ya paradojal, la propia Constitución ha contemplado el derecho a defensa jurídica, que debe ser entendido en sentido amplio, no sólo para el imputado sino también para el ofendido, ya que al ser conceptuado como garantía de la igualdad en el ejercicio de los derechos debe entenderse como defensa de todo interés reclamable ante el órgano jurisdiccional por los intervinientes, como única forma de dar eficacia a dicha igualdad en su ejercicio. 
DECIMOSEGUNDO. Que en el sentido antes expuesto, entender la facultad del Ministerio Público de formalizar la investigación como una alternativa discrecional, en la cual no se puede interferir y de la que pueda derivar la decisión de no investigar y eventualmente archivar, aun cuando el afectado por el delito ha manifestado su voluntad de proseguir la persecución penal mediante la interposición de una querella, como ocurre en el caso sub lite, implica un acto de un órgano del Estado que produce como resultado evidente la negación de la tutela de los intereses penales de la víctima, la privación del derecho a la investigación del hecho delictivo y la imposibilidad de acceder a la jurisdicción, para que ésta resuelva el conflicto penal que la afecta, como lo ordena el artículo $7^{\circ}$ de la Constitución.

De lo anterior se desprende que al ser la tutela judicial efectiva un derecho fundamental, es la persona titular de dicho derecho violentado la que debe disponer del mismo a la hora de resolver si acude o no a la justicia, teniendo presente que el ejercicio y la titularidad de sus derechos se encuentran dentro de la órbita de decisión del ser humano, coto vedado al poder público al estar dentro del marco de lo íntimo e individual, sin que el Estado pueda realizar injerencias dentro de dichos ámbitos. Es por ello que cualquier concepción que prescinda del interés de la víctima, como parte primordial del proceso penal, debe considerarse incompatible con la Constitución, principio que surge nítidamente a la luz de la historia fidedigna de la Ley $\mathrm{N}^{\circ} 19.519$ de 1997, que sin lugar a dudas de ninguna especie buscó dejar a salvo el rol y los derechos del ofendido, fortaleciendo justamente las garantías resultantes de la tutela judicial efectiva por la vía de salvar expresamente el derecho a la querella y a la investigación racional y justa.

En efecto, como lo señalara esta Magistratura en su reciente sentencia Rol No 986 , “...Desde una perspectiva constitucional, y de derechos fundamentales, el debido proceso se traduce no sólo en las garantías del imputado, sino también en el derecho a acceder a la justicia de la víctima para perseguir la reparación del mal causado y el castigo a los culpables, a través de los medios establecidos en la ley procesal y traducidos en el proceso en contra del imputado. Por ende, deben descartarse todas las interpretaciones que, a pretexto de las garantías del imputado, lesionen el derecho de la víctima y de los organismos encargados de protegerla para buscar la aplicación de la sanción prevista por la ley y la reparación del mal causado".

DECIMOTERCERO. Que en cumplimiento del mandato señalado en el artículo 19 número $3^{\circ}$ de la Constitución, el Título III del Libro I del Código Procesal Penal contempla y regula el ejercicio de la acción penal, sin definirla, para precisar sus distintas clases y los sujetos legitimados para ejercerla en cada caso.

El inciso segundo del artículo 53 señala: "La acción penal pública para la persecución de todo delito que no esté sometido a regla especial deberá ser ejercida de oficio por el ministerio público. Podrá ser ejercida, además, por las personas que determine la ley, con arreglo a las disposiciones de este Código. Se concede siempre acción penal pública para la persecución de los delitos cometidos contra menores de edad".

Por su parte y complementando lo expuesto, el artículo 54 contiene los delitos que denomina "de acción pública previa instancia particular", en el que se expresa que "no podrá procederse de oficio sin que, a lo menos, el ofendido por el delito bubiere denunciado el becho a la justicia, al ministerio público o a la policía". 
DECIMOCUARTO. Que debe entenderse que la expresión “a lo menos” aludida anteriormente se opone a la expresión “a lo más”, que en este caso sería ejercer la acción mediante la querella, en concordancia con el artículo 109, letra b).

La querella, como acto procesal del sujeto activo, se encuentra reconocida por el artículo 83 de la Constitución y sólo regulada por el Párrafo VII, Título IV, Libro I, del Código Procesal Penal; ella puede ser presentada en cualquier momento mientras el fiscal no declare cerrada la investigación.

En consecuencia, el juez accionado por una querella tiene dos alternativas:

a) La declara inadmisible, no sometiéndola a tramitación, lo que está regulado expresamente por el artículo 114 del Código, que establece sólo cinco causales para decretarlo así, sin perjuicio de la aplicación de lo dispuesto en el artículo 117.

a) Admitirla a tramitación, lo que produce como su natural efecto la apertura del proceso penal, formándose una relación procesal simple, que continúa con su remisión al Ministerio Público para que éste realice la investigación de los hechos denunciados como delito.

Si el ejercicio de la acción penal pública, como se sostiene, le correspondiere sólo y siempre al Ministerio Público, el Código debiera haber establecido que la querella se presentara ante el referido órgano; en cambio, en concordancia con la normativa constitucional, dispuso que debía ser presentada directamente ante el juez competente, su destinatario natural. Declarada admisible la querella, la resolución que así lo decide es inapelable y el proceso queda abierto para el solo efecto de que se formalice.

Así reglamenta la ley, de forma incompleta, el derecho constitucional que el artículo 83 de la Constitución entrega al ofendido, que el Código Procesal Penal asimila a la víctima, para el ejercicio de la acción penal pública, ya que su prosecución efectiva queda subordinada a la voluntad del Ministerio Público.

DECIMOQUINTO. Que, por otra parte, debe considerarse que la reforma constitucional, al restablecer la institución del Ministerio Público en nuestro procedimiento penal, lo hace convirtiéndolo, en esta oportunidad, en el principal actor de la persecución penal, traspasándole en gran medida la facultad de conocer que tenían los jueces en esta materia a los fiscales, otorgándoles en esencia la facultad de dirigir la investigación y de ejercer, en un concepto amplio, la acción penal.

Resulta, a este respecto, conveniente recordar que cuando existían los promotores fiscales eran ellos quienes acusaban, abriendo la fase de plenario del proceso penal.

En cambio, ahora, al Ministerio Público se le entrega un espectro de facultades más amplias.

DECIMOSEXTO. Que, como se dijo en las consideraciones generales de esta sentencia, la acción procesal penal es el derecho que tienen los sujetos legitimados para impulsar la apertura de un proceso penal. Este derecho básico en un Estado democrático implica la compensación constitucional de la prohibición y sanción de la autotutela o fuerza bruta en la solución de los conflictos penales. 
Esta acción, tradicionalmente, tenía como sujeto destinatario al juez competente, mas hoy en Chile, en esta fase, la Constitución ha dispuesto un operador intermedio entre el actor y el juez, que es el Ministerio Público.

Esta norma se ve complementada por los artículos 79 y 80 del Código Procesal Penal, en cuanto establecen el rol de las policías en el sistema y las bases fundamentales de su relación funcional con los fiscales. Dichas normas disponen:

"Articulo 79. Función de la policía en el procedimiento penal. La Policía de Investigaciones de Chile será auxiliar del ministerio público en las tareas de investigación y deberá llevar a cabo las diligencias necesarias para cumplir los fines previstos en este Código, en especial en los artículos 180, 181 y 187, de conformidad a las instrucciones que le dirigieren los fiscales. Tratándose de delitos que dependieren de instancia privada se estará a lo dispuesto en los artículos 54 y 400 de este Código. Asimismo, le corresponderá ejecutar las medidas de coerción que se decretaren.

Carabineros de Chile, en el mismo carácter de auxiliar del ministerio público, deberá desempeñar las funciones previstas en el inciso precedente cuando el fiscal a cargo del caso así lo dispusiere.

Sin perjuicio de lo previsto en los incisos anteriores, tratándose de la investigación de hechos cometidos en el interior de establecimientos penales, el ministerio público también podrá impartir instrucciones a Gendarmería de Chile, que actuará de conformidad a lo dispuesto en este Código.

Artículo 80. Dirección del ministerio público. Los funcionarios señalados en el artículo anterior que, en cada caso, cumplieren funciones previstas en este Código, ejecutarán sus tareas bajo la dirección y responsabilidad de los fiscales y de acuerdo a las instrucciones que éstos les impartieren para los efectos de la investigación, sin perjuicio de su dependencia de las autoridades de la institución a la que pertenecieren.

También deberán cumplir las órdenes que les dirigieren los jueces para la tramitación del procedimiento.

Los funcionarios antes mencionados deberán cumplir de inmediato y sin más trámite las órdenes que les impartieren los fiscales y los jueces, cuya procedencia, conveniencia y oportunidad no podrán calificar, sin perjuicio de requerir la exbibición de la autorización judicial previa, cuando correspondiere, salvo los casos urgentes a que se refiere el inciso final del artículo $9^{\circ}$, en los cuales la autorización judicial se exhibirá posteriormente".

Más adelante se precisará que la voz "acción penal” la emplea el Código del ramo en reiteradas oportunidades, asimilándola a derechos procesales que se pueden hacer valer ante el juez competente.

DECIMOSÉPTIMO. Que, sobre el particular, hay tesis procesales que sostienen que la acción se extingue conjuntamente con la apertura del proceso y otros que estiman que se está ejerciendo la acción procesal cada vez que se realiza una actividad por parte del sujeto activo, como especialmente ocurre en los casos de la formalización y de la acusación.

Es en tal contexto que hay que entender la nomenclatura que emplea el Código Procesal Penal. Por ahora debe afirmarse que cualquiera que sea la doctrina que se siga sobre el concepto de la acción procesal, ésta comprende el derecho de activar al organismo 
competente para que abra la investigación, tratándose del Ministerio Público, o el proceso jurisdiccional, tratándose del Tribunal.

Así, los actores clásicos del sistema procesal penal, como la policía, hoy accionan ante el Ministerio Público y no ante el juez, lo que genera importantes efectos como más adelante se analizará. Ello significa que la denuncia, clásica forma de iniciar la acción penal pública, tiene como destinatario al Ministerio Público y no al Tribunal, como lo dispone el artículo 173 del Código, que dice:

“Artículo 173. Denuncia. Cualquier persona podrá comunicar directamente al ministerio público el conocimiento que tuviere de la comisión de un hecho que revistiere caracteres de delito.

También se podrá formular la denuncia ante los funcionarios de Carabineros de Chile, de la Policía de Investigaciones, de Gendarmería de Chile en los casos de los delitos cometidos dentro de los recintos penitenciarios, o ante cualquier tribunal con competencia criminal, todos los cuales deberán hacerla llegar de inmediato al ministerio público"..

DECIMOCTAVO. Que, enfrentado a decidir sobre este requerimiento, lo que corresponde ahora es determinar cuáles son los derechos que le asisten al querellante dentro del nuevo proceso penal, emanados de la resolución que admite a tramitación la querella y ordena su envío al Ministerio Público. Luego cabrá precisar si el Ministerio Público debe cursarla o puede inadmitirla y cuáles serían sus consecuencias constitucionales.

En este sentido, debemos recordar nuevamente que la Constitución Política, en el inciso segundo del artículo 83, legitimó a la víctima u ofendido como sujeto titular de la acción que estamos analizando, al disponer que "el ofendido por el delito y las demás personas que determine la ley, podrán ejercer igualmente la acción penal".

La voz ofendido ha de entenderse asimilada al concepto de víctima del delito, en virtud de lo dispuesto por la definición contenida en el artículo 108 del Código, en cuanto expresa que "se considera víctima al ofendido por el delito", y al agregar en el inciso segundo que "en los delitos cuya consecuencia fuere la muerte del ofendido y en los casos en que éste no pudiere ejercer los derechos que en este Código se le otorgan, se considerará víctima: a) al cónyuge y a los hijos; b) a los ascendientes; c) al conviviente; d) a los hermanos, y e) al adoptado o adoptante"... Lo anterior se ve confirmado por el artículo 111, que legitima a la víctima como querellante.

Debe destacarse la voz "igualmente" que emplea el artículo 83, inciso segundo, antes citado de la Carta Fundamental, la cual debe leerse en su único sentido posible, esto es, que el Ministerio Público ejerce la acción penal pública, como igualmente puede hacerlo la víctima que la Constitución denomina ofendido y además los otros sujetos que la ley determine.

Es claro que existen tres órdenes de sujetos legitimados, de acuerdo al tenor del artículo 83: el Ministerio Público, la víctima y, finalmente, los otros sujetos que la ley señale.

Resulta necesario precisar lo anterior, por cuanto el Ministerio Público, representado por su Fiscal Nacional, Sabas Chauán Sarrás, señala, en su escrito de observaciones al requerimiento, que la expresión "igualmente”, contenida en el artículo 83 en comento, 
"no puede significar plena igualdad en el ejercicio de la acción penal por parte del Ministerio Público y el que pueda hacer el ofendido. Entonces, aquella expresión debe necesariamente entenderse en referencia a las condiciones que la propia Carta Fundamental ha impuesto al ejercicio de la acción penal por parte del acusador fiscal, esto es, el ejercicio de la acción "en su caso", y "en la forma prevista por la ley", lo que nos conduce al respectivo Código Procedimental".

DECIMONOVENO. Que, en el mismo sentido, debe tenerse presente lo razonado de manera reiterada por esta Magistratura, en orden a que el artículo 19 número tercero de la Constitución, al consagrar la igualdad en el ejercicio de los derechos y la garantía del procedimiento racional y justo ha establecido a la acción, entendida como el derecho fundamental al proceso (ver, entre otras, sentencias de los procesos roles 389, $478,529,533,661,568,654,806$ y 986), concepto hoy difundido en el mundo como el denominado derecho a la tutela judicial efectiva, ya considerado en esta sentencia. En este orden, la querella y el ejercicio de la acción por parte de la víctima han de ser entendidas como manifestaciones del legítimo ejercicio de dicho derecho al proceso, por lo que el mismo no puede ser desconocido, ni menos cercenado, por el aparato estatal.

VIGÉSIMO. Que, a este respecto, cabe mencionar que el conflicto de este proceso es una controversia de constitucionalidad sobre un precepto legal puesto en aplicación. En este sentido, se hace necesario constatar la improcedencia de usar la ley como parámetro o elemento de interpretación de la Constitución a la hora de determinar el sentido de sus normas, pues con ello se somete a la norma constitucional, con infracción patente de la lógica, a los preceptos legales que se le hallan subordinados y eventualmente pugnan con ella.

En el marco de la precisión conceptual anterior, resulta necesario recurrir a la historia fidedigna del establecimiento de la Ley $\mathrm{N}^{0}$ 19.519, reforma constitucional que creó el Ministerio Público, cuyo mensaje no contemplaba a la víctima como sujeto legitimado para el ejercicio de la acción penal pública. Como consecuencia de lo anterior, el proyecto original fue objeto de indicaciones para dejar a salvo el derecho a ejercer la acción por parte del ofendido del delito.

En efecto, el texto original del mensaje establecía que "Existirá un organismo autónomo, con patrimonio propio, denominado Ministerio Público, que tendrá a su cargo la persecución penal pública en la forma prevista por la ley. Con este propósito, le corresponderá la investigación de los delitos y la formulación y sustentación de la acusación penal ante los tribunales", entendiéndose en la Comisión de Constitución del Senado que a dicho órgano se le confería el ejercicio exclusivo de la acción penal. Por lo anterior, ya en el primer trámite constitucional se presentaron indicaciones en orden a permitir claramente el ejercicio de la acción penal pública al ofendido por el delito.

En este sentido, resultan muy ilustrativos los pasajes sobre este tema del primer informe de la Comisión de Constitución, Legislación, Justicia y Reglamento del Senado, que señala: 
"En cuanto a las funciones y atribuciones, la indicación asigna al Ministerio Público las de ejercer la acción penal pública en la forma prevista por la ley, para lo cual le corresponderá, en forma exclusiva, investigar los hechos que configuren un delito, los que determinen una participación punible en él y los que acrediten la inocencia del imputado; adoptar medidas para amparar y proteger a las víctimas y a los testigos; impartir órdenes directas durante la investigación a la policía, la que deberá cumplirlas de inmediato y no podrá calificar su fundamento, oportunidad, justicia o legalidad; empero, si dichas órdenes pudieren perturbar o vulnerar derechos del imputado o de terceros garantizados por la Constitución, requerirán orden judicial previa. El ejercicio de la acción penal por parte del Ministerio Público no priva al ofendido de su derecho a querellarse".

...

"El reemplazo de la frase "tendrá a su cargo la persecución penal pública" por "ejercerá la acción penal pública", obedece a que la Comisión consideró que esta última resulta más apropiada a la naturaleza no jurisdiccional de las funciones del Ministerio Público. En efecto, la persecución de los delitos es el ejercicio de la facultad punitiva del Estado, que actualmente corresponde en exclusividad a los tribunales del crimen, en tanto que el ejercicio de la acción, que supone acusar y probar la acusación, incumbe a quien ocurre ante un órgano jurisdiccional demandando que sea satisfecha su pretensión de proteger un bien jurídico vulnerado.

Otra diferencia importante radica en que el Mensaje reservaba el monopolio exclusivo de la acción penal pública al Ministerio Público. La indicación, como se dijo, deja abierta también la posibilidad de accionar al ofendido, en conformidad a la ley. Es claro que el fiscal y la víctima pueden discrepar en cuanto al carácter de la participación del inculpado y a la calificación jurídica de los hechos, así como en el ejercicio mismo de la acción penal. En tal sentido, si quien ha sufrido las consecuencias del delito, o sus representantes, no se conforman con la decisión del Ministerio Público, podrán accionar por su cuenta, en la forma que señale la ley procesal penal.

La consagración constitucional de este derecho del ofendido es una concreción, en este plano, de las garantías fundamentales de orden procesal que asegura el número $3^{\circ}$ del artículo 19 de la Carta Fundamental".

VIGESIMOPRIMERO. Que, en el mismo sentido, la Comisión de Constitución, Legislación y Justicia de la Cámara de Diputados se refirió en detalle al tema, aludiendo al nuevo Código y señalando en su primer informe:

"El Ministerio Público puede ser renuente a investigar, pues tiene la posibilidad de no iniciar la investigación o de abandonar la ya iniciada, o de resolver el archivo provisional de los antecedentes.

El proyecto de nuevo Código regula la no iniciación de la investigación, indicando que, si el Ministerio Público resuelve no iniciar la investigación, la víctima, mediante la interposición de la querella, puede provocar la intervención del juez, el que, si la admite a tramitación, obliga al Ministerio Público a investigar.

Si el Ministerio Público resuelve el archivo provisional de los antecedentes, la víctima tiene el derecho de solicitar del fiscal la reapertura del procedimiento y la realización de diligencias de investigación; puede reclamar también ante las autoridades superiores del Ministerio Público y, por último, interponer una querella, la que, admitida por el juez, genera la obligación de investigar para el Ministerio Público. 
El efecto principal de estas normas es que el Ministerio Público no tiene el monopolio de la acción penal. En esta etapa previa, la resistencia del Ministerio Público a investigar está sujeta al control del juez".

Se agrega en dicho informe que:

"En vez de hablar de un racional y justo procedimiento, se propone establecer la garantía de un procedimiento y una investigación racionales y justos.

La nueva disposición apunta a exigir que la investigación que pudiera dar lugar a un proceso se deberá ceñir también a los requisitos de justicia y racionalidad. Si se tiene en cuenta que el proyecto en informe deja claramente sentado que la pesquisa que realice el Ministerio Público no tiene carácter jurisdiccional, resulta imperativo, entonces, sujetarla también, y expresamente, a las exigencias que la Carta Fundamental impone al procedimiento".

.........

"El ejercicio de la acción penal por parte del Ministerio Público no priva al ofendido y a las demás personas que determine la ley para ejercer igualmente la acción penal, en alguna de las formas que el Código del ramo determine.

En esta parte, hay una diferencia importante entre el mensaje y el texto que se comenta. El primero reservaba el monopolio exclusivo de la acción penal pública al Ministerio Público. El segundo, en cambio, deja abierta también la posibilidad de accionar al ofendido, en conformidad a la ley.

Es claro que el fiscal y la víctima pueden discrepar en cuanto al carácter de la participación del inculpado y a la calificación jurídica de los hechos, así como en el ejercicio mismo de la acción penal. En tal sentido, si quien ha sufrido las consecuencias del delito, o sus representantes, no se conforman con la decisión del Ministerio Público, podrán accionar por su cuenta, en la forma que señale la ley procesal penal.

La consagración constitucional de este derecho del ofendido es una concreción, en este plano, de las garantías fundamentales de orden procesal que asegura el número $3^{\circ}$ del artículo 19 de la Carta Fundamental".

VIGESIMOSEGUNDO. Que, dentro del mismo informe, cabe destacar con especial mención lo señalado por el entonces diputado señor José Antonio Viera-Gallo, pues permite ilustrar la estructura conceptual del nuevo proceso penal y el trasfondo de la discusión acerca del rol de la víctima y su derecho a querellarse, contemplado en el actual artículo 83 de la Constitución:

"En relación con este artículo, el señor Viera-Gallo pidió que se dejara constancia en el informe que la filosofía de la reforma del sistema procesal penal es que el monopolio de la acción penal pertenece al Ministerio Público, de manera tal que el afectado por un delito no puede acudir directamente ante un tribunal y ejercerla. Para precaver que el Ministerio Público no ejerza la acción penal pública se estableció un recurso ante el juez de control de la instrucción, que es el que decide si se ejerce o no se ejerce la acción.

A su juicio, el texto de la reforma constitucional permite la desnaturalización del proceso penal como ha sido concebido, ya que consagra dos caminos para el ejercicio de la acción penal, situación que se ha acentuado en el caso de la justicia militar, en la cual debe garantizarse la posibilidad de reclamar ante el juez militar en el caso de que el fiscal no realice la investigación. 
En relación con lo anteriormente afirmado se señaló que lo que estaba absolutamente claro era que el Ministerio Público tiene el monopolio de la investigación y que en caso alguno se podrá prescindir de él en el ejercicio de esta función".

El texto aprobado en primer trámite, finalmente, según consta del oficio respectivo, es el siguiente:

"Artículo único. Introdúcense en la Constitución Política de la República, las siguientes modificaciones:

1. Reemplázase, en el inciso quinto del número $3^{\circ}$ del artículo 19, la frase "un racional y justo procedimiento", por la siguiente: "un procedimiento y una investigación racionales y justos".

...

7. Agrégase, a continuación del Capítulo VI, el siguiente Capítulo VI-A:

"Capítulo VI-A

MINISTERIO PÚBLICO

Artículo 80 A. Un organismo autónomo, jerarquizado, con el nombre de Ministerio Público, dirigirá en forma exclusiva la investigación de los hechos constitutivos de delito, los que determinen la participación punible y los que acrediten la inocencia del imputado y, en su caso, ejercerá la acción penal pública en la forma prevista por la ley. De igual manera, le corresponderá la adopción de medidas para proteger a las víctimas y a los testigos. En caso alguno podrá ejercer funciones jurisdiccionales.

El ofendido por el delito y las demás personas que determine la ley podrán ejercer igualmente la acción penal.

El Ministerio Público podrá impartir órdenes directas a las Fuerzas de Orden y Seguridad durante la investigación. Sin embargo, las actuaciones que priven al imputado o a terceros del ejercicio de los derechos que esta Constitución asegura, o lo restrinjan o perturben, requerirán de aprobación judicial previa. La autoridad requerida deberá cumplir sin más trámite dichas órdenes y no podrá calificar su fundamento, oportunidad, justicia o legalidad, salvo requerir la exhibición de la autorización judicial previa, en su caso.

El ejercicio de la acción penal pública, y la dirección de las investigaciones de los hechos que configuren el delito, de los que determinen la participación punible y de los que acrediten la inocencia del imputado en las causas que sean de conocimiento de los tribunales militares, como asimismo la adopción de medidas para proteger a las víctimas y a los testigos de tales hechos corresponderá a los órganos establecidos en el Código de Justicia Militar, en conformidad a las normas de este Código y las leyes respectivas".

VIGESIMOTERCERO. Que cabe señalar que para allegar a la redacción final de tan discutida norma, ella fue objeto, durante la continuación de su tramitación en el Senado, de indicaciones, según consta en las actas respectivas. En efecto, la primera de ellas "de los HH. Senadores señores Diez y Piñera, y la segunda, del H. Senador señor Urenda, modifican el inciso tercero del artículo $80 \mathrm{~A}$, recién mencionado. Ambas permiten a toda persona, en la forma y en los casos que determine la ley, el ejercicio de la acción penal", agregando posteriormente que "La importancia del inciso tercero en comento estriba en que permite accionar a la víctima en caso que el Ministerio Público no lo haga, o en que aquélla no se conforme con el 
sentido que éste hubiera impreso al procedimiento. Por último, las indicaciones dejan a salvo la acción popular que en algunos casos conceden las leyes".

Ambas indicaciones conducen a permitir que toda persona tenga la facultad de impulsar la apertura de un proceso penal.

VIGESIMOCUARTO. Que de las consideraciones expuestas y de la historia de la norma cabe entonces concluir que el derecho al ejercicio de la acción penal se encuentra consagrado de forma expresa y categórica por la Constitución.

Acorde con lo antes expuesto, es esta misma reforma constitucional la que introduce el texto actual del inciso quinto del numeral $3^{\circ}$ del artículo 19 de la Carta Fundamental, sustituyendo la expresión "racional y justo procedimiento" por "un procedimiento y una investigación racionales y justos", a efectos de incluir, de manera indubitada y omnicomprensible, dentro de dichas garantías la actuación del Ministerio Público en la etapa de investigación.

Dicha reforma fue introducida por vía de indicación, de los senadores Piñera y Diez, siendo aprobada en los términos siguientes en la comisión:

"Indicación número 1

De los HH. Senadores señores Diez y Piñera, para insertar un número nuevo, que agrega al final del inciso quinto del número $3^{\circ}$ del artículo 19 de la Constitución, las palabras "e investigación".

El precepto citado consagra la garantía constitucional de igual protección legal en el ejercicio de los derechos de las personas. El inciso quinto se refiere específicamente a la que se ha denominado garantía del debido proceso.

Según manifestó el H. Senador señor Diez, la indicación apunta a exigir que la investigación que pudiera dar lugar a un proceso se deberá ceñir también a los requisitos de justicia y racionalidad. Si se tiene en cuenta que el proyecto en informe deja claramente sentado que la pesquisa que realice el Ministerio Público no tiene carácter jurisdiccional, resulta imperativo, entonces, sujetarla también, y expresamente, a las exigencias que la Carta Fundamental impone al procedimiento.

De otro punto de vista, la indicación también se justifica, en opinión de su autor, porque, dado que la Constitución no fija más límites o parámetros para lo que debe entenderse por un debido proceso que la justicia y la racionalidad, vale la pena hacer el mismo encargo al legislador en el caso de la investigación de delitos que dirigirá el Ministerio Público. Tal explicitación es necesaria puesto que esa investigación, como no es jurisdiccional, no estaría constreñida por los principios mencionados.

La Comisión la aprobó unánimemente, con los votos de los HH. Senadores señores Fernández, Hamilton, Otero y Sule, con modificaciones de redacción que permiten su mejor inserción en el texto vigente".

VIGESIMOQUINTO. Que para una acertada resolución, esta Magistratura necesariamente debe retomar el examen del marco jurídico constitucional y su aplicación por la ley, donde opera la norma cuya constitucionalidad se cuestiona, pues serán los efectos de su aplicación los que constituirán el elemento que sustentará su decisión. 
En la gestión pendiente sub lite tienen incidencia directa e inmediata el inciso primero del artículo 83 de la Constitución, en cuanto establece al Ministerio Público como director de la investigación, el inciso segundo de la misma norma, en cuanto asegura el derecho a la acción para el ofendido por el delito, es decir, la víctima, el artículo 19 número $3^{\circ}$ de la Constitución, en cuanto asegura y consagra a toda persona el derecho al proceso e investigación racionales y justos, el alcance y el ámbito de aplicación del artículo 230 del Código Procesal Penal, enfrentado a la normativa constitucional, especialmente al artículo 83, y el artículo 76 de la Carta Fundamental, en tanto establece la jurisdicción del juez con competencia penal en los procesos por delito de acción pública.

\section{Atribuciones del Ministerio Público en la etapa DE INICIACIÓN DEL PROCESO PENAL}

VIGESIMOSEXTO. Que, interpretada la voz "igualmente” que emplea el artículo 83 en el sentido que ya se ha establecido en considerandos anteriores, debemos ahora reflexionar sobre la expresión "dirigirá” la investigación penal.

De las facultades que tiene el Ministerio Público, en lo que interesa, destaca la expresión "dirigirá”, que, a juicio de este Tribunal, produce dos efectos fundamentales, a saber: le otorga el poder de dirigir la investigación, que el Ministerio Público debe ejercer. En segundo lugar, lleva implícito el deber de hacerlo, como se desprende del vocablo señalado y del mandato contemplado en el artículo $6^{\circ}$ de la Carta Fundamental.

Lo anterior significa que el Ministerio Público, representado por sus fiscales, debe cumplir con el deber de dirigir en forma exclusiva la investigación criminal, puesto que si no lo hace, no hay ninguna otra autoridad que lo reemplace y en consecuencia el proceso no llegaría a iniciarse, y menos emplearse, como la forma de solución del conflicto penal.

Lo segundo que debe destacarse es determinar cuál es la atribución en torno a la dirección de la investigación, en otros términos, si la misma debe ser efectuada materialmente por el Ministerio Público, o éste debe limitarse a dirigir a los organismos policiales y científicos establecidos para ello, lo que, como ya se vio, quedó establecido de forma expresa en los artículos 74 y 80 del Código, que demarcan los límites de ese poder de dirección investigativa. En este orden conceptual, hemos de entender que dirigir, según el diccionario de la Real Academia Española, significa "Enderezar, llevar rectamente algo hacia un término o lugar señalado", "Guiar, mostrando o dando las señas de un camino", "Encaminar la intención y las operaciones a determinado fin", "Gobernar, regir, dar reglas para el manejo de una dependencia, empresa o pretensión", "Orientar, guiar, aconsejar a quien realiza un trabajo".

Esto permite diferenciar la investigación jurisdiccional clásica del delito con la que el artículo 83 de la Constitución le confiere al Ministerio Público. La primera es amplia y está enmarcada en la facultad de "conocer" que la Constitución entrega a todos los tribunales de la República, que es la que le permite formarse, a través del proceso, la plena convicción establecida en el artículo 340 del Código Procesal Penal, que establece:

“Artículo 340. Convicción del tribunal. Nadie podrá ser condenado por delito sino cuando el tribunal que lo juzgare adquiriere, más allá de toda duda razonable, la convicción de que 
realmente se hubiere cometido el hecho punible objeto de la acusación y que en él hubiere correspondido al acusado una participación culpable y penada por la ley.

El tribunal formará su convicción sobre la base de la prueba producida durante el juicio oral.

No se podrá condenar a una persona con el solo mérito de su propia declaración".

En cambio, a juicio de este Tribunal, la investigación que realiza el Ministerio Público tiene limitaciones derivadas del propio texto de la Constitución -su carácter administrativo- y, en el contexto del nuevo sistema procesal penal, su función se cumple proporcionando los elementos necesarios para que los tribunales puedan dictar una sentencia de acuerdo al mérito del proceso.

VIGESIMOSÉPTIMO. Que cabe destacar que el Constituyente delegó en el legislador orgánico constitucional la regulación de las materias contempladas por el artículo 84. Es en cumplimiento de dicho mandato que se dicta la Ley $\mathrm{N}^{\circ} 19.640$, Orgánica Constitucional del Ministerio Público, que en lo que interesa, en su artículo primero, reitera lo dispuesto en el artículo 83 de la Constitución. En su artículo $3^{\circ}$ establece que en el ejercicio de su función los fiscales adecuarán sus actos a un criterio objetivo, velando correctamente por la aplicación de la ley. El resto de la normativa se destina a regular el estatuto de personal y a establecer los órganos de dicha institución.

VIGESIMOCTAVO. Que, considerado lo anterior, debemos precisar que, de las atribuciones del Ministerio Público que inciden en la aplicación del precepto impugnado al caso objeto del requerimiento, cabe destacar la de dirigir, en forma exclusiva, la investigación de los hechos que la Constitución califica como constitutivos de delito y que en el sistema procesal chileno son equivalentes a los hechos que revisten caracteres de delito, al hecho punible. Resulta indispensable clarificar esta terminología, puesto que la existencia misma del delito surge con la sentencia que le pone término al proceso, pero para iniciar una investigación todos los sistemas del mundo, entre ellos el chileno, precisan que resulta suficiente que el hecho a investigar sólo revista los caracteres de un delito, es decir, que a lo menos tenga la apariencia del mismo, puesto que, de lo contrario, o no se necesita investigar nada o no se puede investigar nada, al carecer el órgano persecutor de competencia para investigar hechos que no son delitos. Enfrentados a esta premisa, el problema consiste en decidir quién es el que califica si el resultado de la acción de un sujeto responde a un tipo penal, es decir, si es o no punible.

Dicha calificación provisional, en nuestro sistema, puede emanar, entre otros, de los siguientes sujetos: en primer término, de la víctima, quien sufre las consecuencias del referido hecho. En segundo lugar, otra persona que tome conocimiento del hecho punible, que generalmente es un particular o la policía. Puede también conocerlo directamente el fiscal o, en su caso, un tribunal.

Todas las noticias acerca de la existencia de este hecho, antes de la reforma, se ponían en conocimiento del tribunal o sus agentes a través de la denuncia. En el sistema actual se canalizan exclusivamente a través del Ministerio Público, que es el receptor de la noticia y que deberá recalificar el hecho a efectos de iniciar o no una investigación. 
Dicha recalificación, previa investigación, es una exigencia que se encuentra establecida en el artículo 166, incisos primero y segundo, del ya citado Código.

En el caso planteado en el requerimiento, el ofendido presentó querella ante el tribunal competente, el que la admitió a tramitación, remitiéndola al Ministerio Público.

El aludido artículo 166 dispone:

"Articulo 166. Ejercicio de la acción penal. Los delitos de acción pública serán investigados con arreglo a las disposiciones de este Título.

Cuando el ministerio público tomare conocimiento de la existencia de un hecho que revistiere caracteres de delito, con el auxilio de la policía, promoverá la persecución penal, sin que pueda suspender, interrumpir o hacer cesar su curso, salvo en los casos previstos en la ley".

Producida dicha investigación y en tanto no hubiere tenido lugar la intervención del juez de garantía, el Ministerio Público podrá archivarla provisionalmente, de acuerdo al artículo 167 del Código Procesal Penal, que establece que:

"En tanto no se hubiere producido la intervención del juez de garantía en el procedimiento, el ministerio público podrá archivar provisionalmente aquellas investigaciones en las que no aparecieren antecedentes que permitieren desarrollar actividades conducentes al esclarecimiento de los hechos.

Si el delito mereciere pena aflictiva, el fiscal deberá someter la decisión sobre archivo provisional a la aprobación del Fiscal Regional.

La víctima podrá solicitar al ministerio público la reapertura del procedimiento y la realización de diligencias de investigación. Asimismo, podrá reclamar de la denegación de dicha solicitud ante las autoridades del ministerio público".

A continuación, el fiscal, de acuerdo al artículo 168, “...podrá abstenerse de toda investigación, cuando los hechos relatados en la denuncia no fueren constitutivos de delito o cuando los antecedentes y datos suministrados permitieren establecer que se encuentra extinguida la responsabilidad penal del imputado".

Seguido a ello, el artículo 169 le otorga a la víctima el derecho a provocar la intervención del juez de garantía deduciendo la querella respectiva ante el juez competente, la que admitida a tramitación lo obliga a seguir adelante la investigación en el contexto expresado.

Para cerrar la caracterización de la investigación, cabe referirse al ya aludido, y denominado por el Código, principio de oportunidad, contenido en el artículo 170 del mismo y que se manifiesta en dos etapas del procedimiento, la primera, producida la investigación, al no iniciar la persecución penal, y la segunda, antes de iniciar la investigación, abandonándola cuando se tratare de un hecho que no comprometiere gravemente el interés público, con las excepciones que contempla el mismo artículo 170 ya referido. Cabe hacer presente que en el caso de una investigación no formalizada se produce una relación exclusiva entre el Ministerio Público y el Juez de Garantía, en la cual la víctima no tiene los derechos procesales derivados de la formalización, por lo que las garantías de impugnabilidad de la aplicación del principio de oportunidad mal pueden ser ejercidas, no existiendo, en este caso, las garantías de una investigación racional y justa a favor de la víctima. Esta norma confirma una vez más la desmedrada posición en que se encuentran los derechos del ofendido, enfrentado a las atribuciones 
del Ministerio Público, lo que exige a esta Magistratura dar eficacia a la disposición constitucional que la autoriza expresamente para ejercer la acción penal.

Si los hechos son constitutivos de delito, el Ministerio Público debe iniciar, a lo menos, una investigación administrativa de los mismos y formalizarla si hay querella admitida a tramitación, como única forma de dar efectividad a la garantía del inciso segundo del artículo 83 de la Constitución.

Diferente es la situación cuando la víctima aparece como interviniente en el proceso y el Ministerio Público manifiesta su decisión de no investigar, según lo señala el citado artículo 170, y el afectado recurre de dicha decisión forzando así la investigación, sin perjuicio de darse la paradoja de que el eventualmente obligado a investigar por el juez será el mismo Ministerio Público y probablemente el mismo fiscal que deseaba aplicar el principio de oportunidad, lo que, más allá de lo que las normas digan, tendrá como efecto que el celo investigativo no será el mismo y que una vez cerrada la investigación, la determinación de acusar no será la misma que en un caso en el que el fiscal sí deseaba investigar. Lo anterior deja de manifiesto, per se, una afectación material y clara del libre y real ejercicio del derecho a la tutela judicial efectiva, traducido en el logro de una investigación racional y justa.

VIGESIMONOVENO. Que, también dentro de la conceptualización de la voz dirección de la investigación que ya se especificara en esta sentencia, es necesario hacer presente que la Constitución confiere al Ministerio Público sólo la dirección de la investigación, y que es el artículo 180 del Código Procesal Penal la norma que faculta a los fiscales a "realizar por sí mismos" las diligencias de investigación.

Resulta de interés destacar el texto del artículo 181, en cuanto señala que “... la investigación se llevará a cabo de modo de consignar y asegurar todo cuanto condujere a la comprobación del hecho...".

TRIGÉSIMO. Que queda claro que el ejercicio de la acción penal pública, en el caso sub lite, destinada a la obtención de un proceso, como ya se dijo en los considerandos respectivos de esta sentencia, surgiría cuando se comunique al imputado ante el tribunal de garantía el desarrollo de la investigación. El artículo 230, nuevamente, se refiere al principio de oportunidad, al señalar en su inciso primero que "El fiscal podrá formalizar la investigación cuando considerare oportuno formalizar el procedimiento por medio de la intervención judicial". La investigación concluye y a continuación el proceso termina o continúa de la siguiente manera:

1) Suspensión condicional del procedimiento en los términos previstos por el artículo 237 del Código Procesal Penal, constituyendo presupuesto para que opere el acuerdo entre el fiscal y el imputado.

Sólo por reforma de noviembre de 2005 se incluyó el siguiente inciso: "La presencia del defensor del imputado en la audiencia en que se ventilare la solicitud de suspensión condicional del procedimiento constituirá un requisito de validez de la misma”.

2) Acuerdo reparatorio, en los términos del artículo 241 del Código. 
3) Sobreseimiento definitivo o temporal.

4) Acusación, en cuyo caso se llega a la etapa de juicio oral y se dicta sentencia definitiva.

TRIGESIMOPRIMERO. Que, finalmente y además de lo anterior, resulta también necesario recordar que dentro de las funciones del Ministerio Público se encuentra asimismo la protección a los testigos y a las víctimas, pudiendo impartir, en el ejercicio de sus funciones, órdenes directas a las fuerzas de orden y seguridad.

\section{Aplicación DEL PRECEPTO IMPUGNADO}

A LA LUZ DE LA NORMATIVA CONSTITUCIONAL

TRIGESIMOSEGUNDO. Que, como ya se dijera, es en este contexto donde corresponde decidir si la aplicación del artículo 230 del Código Procesal Penal al caso sub lite, infringe normas constitucionales.

Para ello debe tenerse especialmente en cuenta que el precepto impugnado entrega al fiscal la determinación discrecional de la oportunidad para formalizar la investigación ante el tribunal.

En este contexto, el Código dispone que en ejercicio de sus potestades persecutorias y de dirección de la investigación, el Ministerio Público está facultado para no iniciar o cesar la investigación de hechos que revisten caracteres de delitos, o determinar discrecionalmente cuándo formaliza si lo hará, en virtud de la normativa antes analizada, y lo que debe decidirse es si el precepto impugnado puede tener aplicación, acorde con la Constitución, en su tenor literal cuando el proceso ya ha sido aperturado por una querella acogida a trámite.

En síntesis, el Código Procesal Penal establece circunstancias en que no obstante haber tomado conocimiento o iniciado una persecución penal por un hecho que reviste caracteres de delito, el Ministerio Público se encuentra habilitado, en los casos en que la ley expresamente lo faculte, para abstenerse de iniciar formalmente investigación, interrumpir la ya iniciada, suspenderla o hacer cesar su curso.

TRIGESIMOTERCERO. Que, en el caso sub lite, la requirente señala que el fiscal se niega a formalizar una investigación iniciada por querella del ofendido, lo que sólo podría hacer cuando previamente no se hubiere producido la intervención del juez. El artículo 168 del Código Procesal Penal, establece que "En tanto no se hubiere producido la intervención del juez de garantía en el procedimiento, el fiscal podrá abstenerse de toda investigación,..." en los siguientes casos:

a) “...cuando los hechos relatados en la denuncia no fueren constitutivos de delito...".

b) “...o cuando los antecedentes y datos suministrados permitieren establecer que se encuentra extinguida la responsabilidad penal del imputado".

El mismo artículo 168 dispone que ello ha de hacerse siempre por resolución fundada y sometida a la aprobación del juez de garantía, de la misma forma que se exige 
también resolución fundada y aprobación del juez de garantía en el caso de aplicarse el principio de oportunidad, como ya se viera.

Por otra parte, mientras el referido juez no hubiere intervenido, el artículo 167 del Código establece que:

"En tanto no se hubiere producido la intervención del juez de garantía en el procedimiento, el ministerio público podrá archivar provisionalmente aquellas investigaciones en las que no aparecieren antecedentes que permitieren desarrollar actividades conducentes al esclarecimiento de los hechos.

Si el delito mereciere pena aflictiva, el fiscal deberá someter la decisión sobre archivo provisional a la aprobación del Fiscal Regional.

La víctima podrá solicitar al ministerio público la reapertura del procedimiento y la realización de diligencias de investigación. Asimismo, podrá reclamar de la denegación de dicha solicitud ante las autoridades del ministerio público".

Resulta de toda evidencia que ya se produjo en el caso sub lite la intervención del juez, con las consecuencias que derivan de las normas ya invocadas, pues, en ejercicio del derecho a interponer querella por parte de la víctima, señala el artículo 169 del Código que "la víctima podrá provocar la intervención del juez de garantía deduciendo la querella respectiva”, la que en caso de ser admitida a trámite produce como efecto que "el fiscal deberá seguir adelante la investigación conforme a las reglas generales", efecto que ya se produjo.

TRIGESIMOCUARTO. Que, enfrentado a resolver el presente requerimiento, este Tribunal debe ejercer su Ministerio, toda vez que ha sido legalmente requerido en materias de su competencia y en tal entorno está facultado para inaplicar cualquier precepto contenido en el Código cuya aplicación resulte contraria a la Constitución.

En este sentido, y atendidos los efectos de la aplicación del precepto impugnado, no nos encontramos en ninguna de las situaciones en las cuales podría darse, eventualmente, una interpretación y aplicación conforme a la Constitución del precepto cuya constitucionalidad se cuestiona, de tal forma de poder dar eficacia al principio interpretativo de conformidad de las normas a la Carta Fundamental, por el cual una norma será contraria a la Constitución sólo cuando no exista posibilidad alguna de comprenderla o darle eficacia dentro del marco de la misma.

Cabe concluir, en síntesis, que la víctima puede siempre interponer su querella, y que el Ministerio Público puede abstenerse de investigar mientras no haya intervenido el juez, para lo cual deberá emitir una resolución motivada, la que será reclamable en todos los casos. En el caso sublite, ello no ha ocurrido, pues el Ministerio Público simplemente se niega a formalizar, sin que emita resolución alguna, impidiendo así el control jurisdiccional de sus actuaciones, única sede en la cual la víctima puede ser amparada efectivamente en sus derechos. Cabe tener presente que, más allá de toda duda, es un hecho que la investigación no ha sido formalizada. Entre las argumentaciones del Ministerio Público se señala que la decisión de formalizar y la determinación del momento de hacerlo serían potestades privativas y exclusivas del mismo. 
TRIGESIMOQUINTO. Que entre los efectos de la formalización, el artículo 233 del Código Procesal Penal establece que "suspenderá el curso de la prescripción de la acción penal en conformidad a lo dispuesto en el artículo 96 del Código Penal”. Como consecuencia, el hecho de no formalizar la investigación impide absolutamente al querellante obtener algún resultado con el ejercicio de la acción penal, pues nunca habrá etapa de investigación y nunca además llegará a juicio oral, por lo que no se podrá lograr el derecho al proceso ni tampoco habrá investigación racional y justa, al punto que incluso en contra de su voluntad procesal la acción puede prescribir.

En este sentido, la norma del Código que debiera ser entendida como el contrapeso a dicha situación fáctica es el artículo 186 del mismo, en tanto expresa que "Cualquier persona que se considerare afectada por una investigación que no se hubiere formalizado judicialmente, podrá pedir al juez de garantía que le ordene al fiscal informar acerca de los hechos que fueren objeto de ella. También podrá el juez fijarle un plazo para que formalice la investigación"; sin embargo, la norma no aclara si se refiere sólo al imputado o también al querellante, lo que es discutido por la doctrina. De la misma forma que una lectura detenida permite ver que se "faculta" al juez, es decir, al usar la expresión "podrá”, parece ser que el juez no está obligado a fijar plazo para formalizar ni tampoco a solicitar la información, con lo cual si cree que no hay mérito para ello podría resolver sencillamente "no ha lugar". Por otra parte, el qué ha de entenderse por "afectada por una investigación" no aparece definido, y es un concepto bastante vago al no referirse de forma clara al objeto de la afectación ni al titular de la misma. Además de ello, la norma en comento no contiene sanciones específicas para el caso del incumplimiento del plazo que eventualmente fije el juez, especialmente teniendo en cuenta que la regla de la preclusión del artículo 17 del Código se establece para los plazos legales establecidos dentro de dicho cuerpo legal, mas no para los plazos judiciales.

TRIGESIMOSEXTO. Que la argumentación del Ministerio Público, en orden a que el querellante puede incluso forzar la acusación y así el juicio oral en los términos del artículo 258 del Código, debe ser descartada, pues resulta de toda evidencia y de mínima lógica elemental que para llegar a la etapa de cierre de investigación y posterior acusación, el nuevo proceso penal requiere de una investigación formalizada, por lo que si hay una negativa sistemática a formalizar, ello nunca podrá ocurrir.

\section{CONSIDERACIONES FINALES}

TRIGESIMOSÉPTIMO. Que de las consideraciones precedentes se desprende que el ofendido está reconocido por el constituyente, en el artículo 83 de la Carta Fundamental, como titular de la acción penal pública y que dicha norma está concebida, como todas las demás aludidas, para que produzca efectos en el nuevo proceso penal.

Consta de los autos traídos a la vista que el requirente, conforme al artículo 109 del Código Procesal Penal, interpuso querella en los mismos y que fue acogida a tramitación por resolución que consta en él. De esta forma se provocó la intervención del 
tribunal, que es señalada en las normas del Código ya transcritas como el resguardo frente a la negativa a investigar por parte del Ministerio Público. Es en este sentido que cabe recalcar que el precepto impugnado otorga a dicho órgano la facultad de formalizar cuando considere oportuno hacerlo "mediante la intervención del tribunal", la que en este caso ya operó, no obstante no haberse formalizado.

TRIGESIMOCTAVO. Que de lo razonado en los considerandos precedentes se desprende claramente cuál es la posición de los sujetos activos en el nuevo proceso penal:

a) El Ministerio Público es la única autoridad competente para recibir las noticias que permiten la investigación de un hecho que reviste caracteres de delito, lo que fluye del texto de los artículos 172 y 173 del Código, que lo autorizan para proceder de oficio o por la recepción de la denuncia que le debe ser remitida por los sujetos habilitados para canalizarla, incluso cuando éste haya sido un tribunal con competencia en materias penales, el que sólo podrá cumplir con lo señalado anteriormente.

b) El Ministerio Público, frente al hecho denunciado, puede provocar la intervención del juez de garantía en el procedimiento, o bien podrá ordenar administrativamente el archivo provisional, de acuerdo al artículo 167 del Código.

Le corresponde al Ministerio Público determinar cuáles serán los hechos punibles que va a investigar, para formalizar dichas investigaciones. Este es un derecho del que habitualmente se hace uso según consta de las estadísticas de público conocimiento y profusa divulgación. La víctima, enfrentada a que su caso no llegue a la justicia, podrá solicitar al propio Ministerio Público la reapertura del procedimiento y la realización de diligencias de investigación, así como reclamar de la denegación a las autoridades superiores de dicho Servicio.

c) Realizada la investigación, podrá formalizarla cuando lo considere oportuno, o bien aplicar el principio de oportunidad.

En consecuencia, hay un conjunto de denuncias que se decidió investigar -no archivarlas- pero que puede decidir no formalizar, o sea, investigar sin archivar y no archivar sin formalizar.

d) Si decide formalizar, le corresponde a la fiscalía decidir la oportunidad en que lo hará, que es precisamente la norma que se impugna por sus efectos en el caso concreto.

e) Las denuncias formalizadas pueden, a su vez, ser suspendidas, para lo cual sólo se requiere el consentimiento del fiscal y del imputado, además de la aprobación del juez de garantía, resolución que puede ser apelada por la víctima y el querellante, sólo a partir de la modificación de la Ley N 20.074 .

f) También puede concluir la fase de investigación mediante un acuerdo reparatorio, en los términos que el Código establece.

g) El fiscal, una vez que se declara cerrada la investigación, puede pedir el sobreseimiento temporal o definitivo.

h) Finalmente, y sólo si no ha ocurrido alguna de las hipótesis antes señaladas, puede llegarse a la etapa de juicio oral si el fiscal decidió formular acusación. 
TRIGESIMONOVENO. Que, por otra parte, acogida a trámite la querella por el juez de garantía, la misma es remitida al Ministerio Público, que, de conformidad a lo ya razonado, debe investigar los hechos punibles que en ella se señalen, en el marco de la tutela judicial efectiva y el derecho a la investigación racional y justa. Sostener lo contrario implicaría dejar al arbitrio del órgano persecutor ambos derechos, de titularidad y ejercicio de la víctima.

Si lo hiciere incurriría en responsabilidades derivadas de infracción a derechos fundamentales y, por ende, serán los jueces competentes para dar efectividad a garantías constitucionales en el proceso penal, verdaderos órganos de protección en el nuevo sistema, y sus superiores jerárquicos, como de la misma forma las autoridades del Ministerio Público, quienes deberán adoptar las medidas necesarias para que se dé eficacia real a la normativa constitucional, ello en cumplimiento de los deberes, reglas y principios contenidos en los artículos $5^{\circ}, 6^{\circ}$ y $7^{\circ}$ de la Carta Fundamental.

CUADRAGÉSIMO. Que el querellante buscó forzar la formalización de la investigación y, en los hechos, hasta la fecha el Ministerio Público no ha formalizado. Por otra parte, el juez de garantía rechazó tal solicitud, señalando que no tenía facultades para ello e indicó también que el artículo 186 del Código permitía sólo al imputado solicitar al juez que fije plazo para la formalización, entendiendo que dicha norma discrimina a la víctima frente al imputado.

En concreto, estamos en presencia de una investigación no formalizada por parte del Ministerio Público, de un querellante que hizo efectivos sus derechos ante el juez de garantía, el que acogió a tramitación la querella remitiéndola al órgano investigador; de una petición del fiscal para que se sobresea la causa no formalizada y una decisión del juez de garantía que la acoge, condenando en costas al querellante.

Apelada dicha resolución, la Corte de Apelaciones la acogió teniendo en cuenta que no puede solicitarse un sobreseimiento si el proceso no se encuentra formalizado, y además revocando la condena en costas.

CUADRAGESIMOPRIMERO. Que la obligación de investigar, entendida como carente de la obligación de formalizar cuando la víctima desea proseguir con el proceso penal, no es conciliable con el derecho a la tutela judicial efectiva, pues significa la denegación de la misma al impedir el acceso al proceso, lo que es particularmente grave cuando la propia resolución judicial que no le da lugar al forzamiento de la formalización reconoce este razonamiento (considerando 11 de la resolución de fecha 4 de enero de 2007, de la Corte de Apelaciones de Rancagua).

CUADRAGESIMOSEGUNDO. Que de todo lo considerado precedentemente surge nítidamente que, en su conjunto, la preceptiva legal que limita el acceso a la jurisdicción resulta contraria a la Carta Fundamental; sin embargo, en esta oportunidad, limitado por el marco de la competencia específica, este Tribunal sólo podrá decidir que la aplicación del impugnado artículo 230 del Código Procesal Penal al caso concreto produce un resultado contrario a la Constitución, en específico al numeral $3^{\circ}$ de su artículo 19 y 
a su artículo 83 , además de sus artículos $1^{\circ}, 5^{\circ}, 6^{\circ}, 7^{\circ}$ y 19 , número $26^{\circ}$, lo que conduce a concluir que si la acción que se contiene en la querella debe contar con la voluntad del Ministerio Público para que tenga efectos, no responde a los principios procesales sobre la investigación de un hecho punible que afecta a la víctima para lograr que la justicia abra proceso y resuelva, en el marco del ejercicio del derecho a la tutela judicial efectiva.

Y VISTOS,

Lo prescrito en los artículos $19, \mathrm{~N}^{\circ} 3,83$ y 93 , inciso primero, $\mathrm{N}^{\circ} 6$, e inciso décimo primero, de la Constitución Política de la República, así como en las disposiciones pertinentes de la Ley N N $^{\circ}$.997, Orgánica Constitucional de este Tribunal Constitucional,

\section{SE RESUELVE,}

Que se acoge el requerimiento de fojas 1 sólo en cuanto se decide que una aplicación de lo dispuesto en el inciso primero del artículo 230 del Código Procesal Penal en el sentido que haga equivalente el poder de los fiscales para formalizar la investigación a ejercer dicha facultad de manera discrecional en términos de no practicarla y, por otra parte, no ponerle término por alguno de los medios legales, hasta la fecha de prescripción del delito, existiendo ejercicio de la acción penal por parte del querellante, produce efectos contrarios a la Constitución. En consecuencia, el precepto legal no puede aplicarse con ese alcance en el caso en que incide el presente requerimiento.

Déjese sin efecto la suspensión del procedimiento. Devuélvase el expediente traído a la vista.

Se previene que los Ministros señores Raúl Bertelsen, Jorge Correa y Francisco Fernández concurren a lo resuelto compartiendo únicamente los considerandos $7^{\circ}$ a 10 y 18 a 24 , y teniendo, en lugar de los restantes, especialmente presente lo siguiente:

I. El problema constitucional que debe resolverse y las principales normas constitucionales que deben confluir a ello.

PRIMERO. Que, tal como ha quedado descrito en la parte expositiva que antecede, el requerimiento solicita que se inaplique el inciso primero del artículo 230 del Código Procesal Penal, que se refiere a la oportunidad en que el fiscal podrá formalizar la investigación, fundado en que su aplicación en la gestión pendiente que lo motiva, hace inviable el ejercicio de la acción penal por parte del querellante particular, derecho reconocido por el artículo 83 de la Constitución Política, que se vería así infringido. El precepto impugnado expresa:

"Artículo 230. Oportunidad de la formalización de la investigación. El fiscal podrá formalizar la investigación cuando considerare oportuno formalizar el procedimiento por medio de la intervención judicial". 
SEGUNDO. Que, en la gestión pendiente en que el precepto se pide inaplicar, el requirente se querelló, en febrero de 2005, por el delito de falsificación de instrumento público, acción que fue declarada admisible por el Juzgado de Garantía de San Fernando. En ese proceso, el actor solicitó al Tribunal apercibir al Ministerio Público a formalizar. Luego de varios incidentes, el 16 de noviembre de 2006, esa solicitud fue denegada, por considerarse que el querellante no tenía la facultad para solicitarla. Éste apeló de esa resolución, procediendo la Corte de Apelaciones de Rancagua a confirmar la resolución apelada, validando, de ese modo, la decisión de no permitir al querellante forzar al Ministerio Público a formalizar.

Por su parte, el Ministerio Público solicitó sobreseer definitivamente la causa. En segunda instancia, esa petición fue denegada con fecha 9 de septiembre de 2005, resolución en la que la Corte de Apelaciones de Rancagua declaró que tanto para solicitar como para decretar el sobreseimiento definitivo, la causa debe encontrarse formalizada.

En base a lo ocurrido en la causa, el querellante y requirente afirma que "no es factible que la formalización, que es la llave de inicio del proceso penal, quede entregada de manera exclusiva y excluyente a un organismo todopoderoso como es el Ministerio Público, el cual puede determinar por sí y ante sí, sin ningún control jurisdiccional cuando formaliza, al margen de consideraciones de racionalidad y de justicia", concluyendo que, siendo la formalización requisito para que la querella efectivamente se tramite, se violentan las normas constitucionales que sustentan su pretensión. De ese modo, el requirente argumenta que se está infringiendo el derecho que le otorga la Constitución al ofendido por el delito, para impulsar primero y ser sujeto activo después, en los procesos penales por acción pública, toda vez que el Fiscal Nacional en su respuesta afirma que la investigación, su duración, si ésta es traspasada al proceso penal, y la oportunidad de la misma, es de su competencia exclusiva en virtud del principio de la oportunidad, contemplado por la ley vigente, que lo habilitaría para formalizar cuando lo considere oportuno.

TERCERO. Que la Carta Fundamental contiene cuatro disposiciones cuya interpretación debe armonizarse para resolver el presente requerimiento:

a) La primera es el derecho a la acción que el artículo 83 de la Carta Fundamental reconoce a toda persona ofendida por un delito. Ella es la que los requirentes reclaman como transgredida por la aplicación del precepto legal impugnado al caso sub lite. Literalmente establece: "El ofendido por el delito y las demás personas que determine la ley podrán ejercer igualmente la acción penal".

b) La segunda disposición corresponde a la protección que el sistema asegura a las pretensiones en juicio, lo que en otros ordenamientos se conoce como el derecho a una tutela judicial efectiva. Se encuentra consagrado en el numeral $3^{\circ}$ del artículo 19 de la Carta Fundamental, especialmente en su inciso primero, que establece: "La Constitución asegura a todas las personas (...) la igual protección de la ley en el ejercicio de sus derechos".

c) La tercera norma que habrá de tenerse especialmente en consideración para resolver el presente requerimiento es la garantía constitucional de un justo y racional procedimiento, conocida en otros sistemas comparados como el derecho 
a un debido proceso. Se encuentra consagrada en el inciso quinto del mismo numeral $3^{\circ}$ del ya citado artículo 19. Literalmente establece: "Toda sentencia de un órgano que ejerza jurisdicción debe fundarse en un proceso previo legalmente tramitado. Corresponderá al legislador establecer siempre las garantias de un procedimiento y una investigación racionales y justos".

d) Por último, la solución de la presente causa requiere considerar también de modo especial la norma constitucional que dispone que al Ministerio Público le corresponde dirigir, de manera exclusiva, la investigación de hechos constitutivos de delitos. El precepto se encuentra consagrado en el inciso primero del artículo 83 de la Carta Fundamental que, en su parte pertinente, establece: "Un organismo autónomo, jerarquizado, con el nombre de Ministerio Público, dirigirá en forma exclusiva la investigación de los hechos constitutivos de delito, los que determinen la participación punible y los que acrediten la inocencia del imputado y, en su caso, ejercerá la acción penal pública en la forma prevista por la ley".

CUARTO. Que, a juicio de estos previnientes, la solución al problema de inaplicabilidad planteado habrá de ser armónica e implicar el respeto y vigencia de las cuatro normas ya transcritas. Así, deberá asegurar la vigencia del derecho a la acción y su efectiva tutela ante los Tribunales, respetar la competencia exclusiva del Ministerio Público para dirigir la investigación del delito, pero, a la vez, asegurar que tal investigación sea racional y justa. Ello resulta imperativo a partir del elemento lógico de interpretación, recogido en múltiples oportunidades por reiterada doctrina de esta misma Magistratura acerca de que la inteligencia que se dé a un precepto de la Carta Fundamental debe resultar armónico con las restantes normas del mismo cuerpo, de modo de asegurar la efectiva vigencia de todos sus preceptos (Véanse, por ejemplo, las sentencias roles 309, 325, 383, 392, 396 y 596). Antes de razonar acerca de aquella fórmula que más se acomode a dar vigencia a las normas transcritas, parece conveniente aportar algunos antecedentes que sirven para fijar el sentido y alcance de cada una de ellas, a lo que se abocan los dos apartados que siguen.

II. Algunas precisiones acerca del derecho a la acción penal y a la igual protección de la ley en el ejercicio de los derechos que la Constitución confiere a los ofendidos por un delito.

QUINTO. Que, tal como ha quedado referido en el considerando tercero, letras a) y b) de esta prevención, nuestra Constitución consagra el derecho a ejercer la acción penal a las personas ofendidas por el delito y, garantiza a ellas, la igual protección de la ley en el ejercicio de los derechos.

Las normas constitucionales transcritas en esas letras implican un reconocimiento expreso e inequívoco del derecho del ofendido por un delito y fijan el límite a la autonomía del legislador a la hora de establecer el marco regulatorio del proceso jurisdiccional como forma de solución del conflicto y de los actos necesarios para abrirlo, 
sustanciarlo y cerrarlo. De ese modo, el derecho, que otros sistemas denominan a la tutela judicial efectiva, asegura que las personas accedan al proceso como medio ordinario de resolución de los conflictos jurídicos y obliga a que las reglas adjetivas procesales así lo resguarden.

SEXTO. Que este derecho incluye, desde luego, el del acceso a la jurisdicción. Este supone el derecho a la acción, consagrado constitucionalmente, la que habrá de producir efectos según apruebe un examen judicial inicial de admisibilidad, que ha de verificarse conforme a requisitos establecidos por la ley; así como también el derecho a la apertura y sustanciación del proceso, en el caso de existir evidencia inculpatoria suficiente como para formular cargos en contra de personas determinadas, lo que también habrá de regular el legislador, en ambos casos por normas que deben de garantizar un procedimiento e investigación racionales y justos.

Coincidimos con lo razonado en el párrafo tercero del considerando $11^{\circ}$ del fallo en el sentido que, en resguardo de este derecho de acción y de tutela judicial, al legislador le está vedado establecer condiciones y requisitos que impidan su libre ejercicio o lo dejen condicionado a la voluntad de alguno de los intervinientes, ya que si lo hiciera incurriría en infracción a numeral $26^{\circ}$ del artículo 19 de la Carta Fundamental. De ese modo, al legislador no le es permitido frustrar la tutela de cualquier derecho o interés reclamable, incluida la materia penal.

SÉPTIMO. Que la voz “ofendido”, a quien el artículo 83 que se viene analizando garantiza el derecho a la acción, se corresponde con el concepto de víctima del delito. Así lo establece el artículo 108 del Código Procesal Penal, que expresa que "se considera víctima al ofendido por el delito" y lo confirma el artículo 111 del mismo cuerpo legal, que legitima a la víctima como querellante. En este sentido, concordamos con lo expresado en el párrafo tercero del considerando $18^{\circ}$ del fallo.

OCTAVO: Que el Ministerio Público ha argumentado que la expresión “igualmente”, contenida en el artículo 83 de la Constitución en comento, "no puede significar plena igualdad en el ejercicio de la acción penal por parte del Ministerio Público y el que pueda hacer el ofendido. Entonces, aquella expresión debe necesariamente entenderse en referencia a las condiciones que la propia Carta Fundamental ha impuesto al ejercicio de la acción penal por parte del acusador fiscal, esto es, el ejercicio de la acción "en su caso", y "en la forma prevista por la ley", lo que nos conduce al respectivo Código Procedimental".

Más allá de las distintas maneras de ejercer la acción penal y de los derechos que cada sujeto legitimado pueda tener en la investigación o en el juicio, cuestión que efectivamente corresponde desarrollar al legislador, con sujeción a la Constitución, desde un punto de vista constitucional es claro que ella asegura tanto el Ministerio Público como al ofendido poder ejercer esa acción y a ambos, en cuanto sujetos legitimados para su ejercicio, se les garantiza igual protección de la ley. Por ende, en estos la ley no les puede discriminar. 
NOVENO. Que lo razonado hasta aquí se ve reafirmado por la historia fidedigna del establecimiento de la Ley $\mathrm{N}^{\circ} 19.519$, reforma constitucional que creó el Ministerio Público, tal como se consigna en aquella parte de la discusión legislativa que se consigna en diversos considerandos del fallo respecto del cual prevenimos.

DÉCIMO. De lo razonado en los considerandos reunidos en el presente apartado debe entonces concluirse que el requirente, en cuanto alega ser víctima de un delito, tiene el derecho constitucional a ejercer la acción penal y la garantía de la igual protección de la ley en el ejercicio de su derecho, el que no puede verse impedido o entrabado por normas de rango inferior al punto de tornarlo imposible o ilusorio.

III. Algunas precisiones acerca de la competencia de investigar que la Carta Fundamental confiere de modo exclusivo al Ministerio Público y de la obligación de que las normas que regulen esa actividad sean racionales y justas.

DECIMOPRIMERO. Que, tal como se consignó en la letra d) del considerando tercero de esta prevención, la Constitución dispone que la dirección de la investigación de un hecho delictual corresponde exclusivamente al Ministerio Público. A efectos del análisis de esta potestad y de su consagración constitucional, parece conveniente volver a transcribir la norma constitucional que así lo consagra:

"Un organismo autónomo, jerarquizado, con el nombre de Ministerio Público, dirigirá en forma exclusiva la investigación de los hechos constitutivos de delito, los que determinen la participación punible y los que acrediten la inocencia del imputado y, en su caso, ejercerá la acción penal pública en la forma prevista por la ley".

La interpretación de esta norma constitucional, para efectos de lo que habrá de resolverse, requiere clarificar el sentido de la exclusividad que la Carta consagra y algunos aspectos acerca de la naturaleza de esta potestad, lo que se hará en los considerandos agrupados en este apartado.

DECIMOSEGUNDO. Que la exclusividad que la Ley Fundamental confiere al Ministerio Público en la dirección de la investigación penal ha de entenderse en su sentido natural de excluir a cualquier otra persona o entidad de realizar esa tarea directiva. En particular, y para efectos de lo que habrá de resolverse, a estos previnientes les parece claro que queda constitucionalmente prohibido a la víctima u ofendido por el delito realizar actividades de esa especie, entre las que naturalmente se cuentan las de dar órdenes a las policías para que realicen actos destinados a esclarecer hechos constitutivos de delitos, o los que determinen la participación punible, o acrediten la inocencia del imputado. Las labores de dirección de la investigación implican también la decisión acerca de la estrategia investigativa y su secuencia. Habrá de razonarse más adelante acerca de si la formalización de la investigación es o no parte de aquellas decisiones de dirección que quedan reservadas al Ministerio Público de modo exclusivo. 
DECIMOTERCERO. Que la que se confiere al Ministerio Público es una potestad pública. En consecuencia, queda sujeta al estatuto constitucional de éstas. Entre las muchas limitaciones a que tal estatuto la somete, se encuentra lo dispuesto en los artículos $6^{\circ}$ y $7^{\circ}$, que obligan a ejercerla en conformidad a normas jurídicas; asimismo la prohibición de que, al ejercerla, se incurra en discriminaciones arbitrarias y, desde luego, la limitación de que su ejercicio no transgreda el derecho a la acción penal o a su tutela efectiva, que se ha analizado en el apartado anterior.

Para garantizar que ello ocurra, la Carta Fundamental ha establecido, entre otras normas, la que se transcribió en la letra c) del considerando tercero. En su virtud, el legislador queda mandatado, pero también obligado, a establecer siempre las garantías de una investigación racional y justa.

DECIMOCUARTO. Que, de ese modo, el Ministerio Público está constitucionalmente dotado de una potestad pública, que ejerce en forma exclusiva, de dirigir la investigación penal, en cuyo ejercicio queda sujeto a respetar el resto de las normas constitucionales y las normas legales que regulen tal actividad, mismas que, por mandato constitucional, deben garantizar que tal investigación sea racional y justa.

IV. De algunas normas legales que han intentado compatibilizar la potestad exclusiva del Ministerio Público para dirigir la investigación con el derecho de la víctima a ejercer la acción penal y a que se le proteja ese derecho.

DECIMOQUINTO. Que naturalmente las posiciones del Ministerio Público y las del ofendido por un delito pueden no coincidir. La solución de estos eventuales conflictos de intereses habrá de respetar todas y cada una de las normas constitucionales, cuya vigencia no cabe sacrificar una en razón de la otra, incluyendo la exclusividad de la potestad de dirección de la investigación por parte del Ministerio Público, como así también el derecho a la acción penal y a su tutela efectiva por parte del ofendido por el delito.

El presente caso es uno de tensión entre las perspectivas del Ministerio Público, que, amparado en la norma legal impugnada y en sus facultades constitucionales de dirigir la investigación, no pretende, por ahora, formalizar la investigación de un hecho de apariencia delictual, y de quien se presenta como ofendido por ese posible delito, a quien la Carta Fundamental le asegura el derecho a la acción y le garantiza protección en el ejercicio de ese derecho. Este último no pretende dirigir la investigación, pero señala que el Ministerio Público, al negarse a formalizar, le impide llegar a un juicio y, con ello, torna ineficaz su derecho constitucional a la acción, que queda así privado de la protección que la Carta Fundamental le garantiza. Antes de analizar como se zanja constitucionalmente este conflicto de intereses entre un órgano del Estado y un particular, cada uno amparado en normas constitucionales diversas, es útil revisar algunas fórmulas que el legislador ha ideado para zanjar conflictos análogos que sí ha previsto.

DECIMOSEXTO. Que para resolver un eventual conflicto de intereses entre el Ministerio Público, cuando éste decidiere, antes de la intervención del juez de garantía, archivar provisionalmente una investigación en la que, a su juicio, no aparecieren 
antecedentes que permitieren desarrollar actividades conducentes al esclarecimiento de los hechos y, por la otra parte, la víctima del delito que se interesare en que se prosiga con la investigación, el artículo 167 del Código Procesal Penal dispone, en su inciso tercero, que la víctima podrá solicitar al propio Ministerio Público la reapertura del procedimiento y la realización de diligencias de investigación. Si el fiscal denegare esa solicitud de la víctima, la ley le confiere a ésta un recurso jerárquico ante las propias autoridades del Ministerio Público. El artículo 169, por su parte, dispone que tanto en el caso en que el Ministerio Público archive provisionalmente la causa como en aquel en que decida no iniciar investigación, la víctima puede provocar la intervención del juez de garantía deduciendo la respectiva querella. Si ésta es admitida a tramitación, el fiscal queda obligado a seguir adelante con la investigación.

DECIMOSÉPTIMO. Que, por su parte, el artículo 168 del Código Procesal Penal confiere al órgano a quien la Constitución asegura la exclusividad en la dirección de la investigación, la facultad para no iniciarla, en tanto no se hubiere producido la intervención del juez de garantía, siempre que se den determinadas condiciones, decisión que no es absoluta ni puede ejercerse sin fundamento, pues la misma norma dispone que debe ser siempre fundada y someterse a la decisión del juez de garantía. Además, y tal como se señaló en el considerando precedente, el artículo 169 establece un mecanismo para que el ejercicio de esa facultad no vulnere los derechos de la víctima.

DECIMOOCTAVO. Que el artículo 183 del Código Procesal Penal dispone que todos los intervinientes en el procedimiento pueden solicitar al fiscal la práctica de diligencias investigativas que consideren pertinentes y útiles para el esclarecimiento de los hechos. Si el fiscal rechazare la solicitud, la norma faculta a la víctima para reclamar ante las autoridades del Ministerio Público. En este evento la ley no dispone que la víctima pueda forzar al fiscal a realizar determinadas diligencias a través del Juez de Garantía. La ley ha optado así, en el caso de verificarse este conflicto, por reforzar la exclusividad del Ministerio Público en la dirección de la investigación.

DECIMONOVENO. Que, entonces, y en virtud de lo dispuesto en el inciso segundo del artículo 169, una víctima que hubiere ejercido su derecho a la acción a través de la querella, tiene, en la medida que la misma se hubiere admitido a tramitación, la aptitud de impedir el archivo provisional y la no iniciación de la investigación por parte del Ministerio Público. Sin embargo, la ley no concede al querellante particular la facultad de imponer al Ministerio Público, ni siquiera con la anuencia del Juez de Garantía, una determinada estrategia investigativa, o la realización de ciertas diligencias específicas. Sin embargo, y esto es lo importante para lo que habrá de resolverse, la ley resuelve el conflicto de intereses entre el Ministerio Público y el querellante particular impidiendo que aquél pueda archivar provisionalmente la causa o no iniciar la investigación.

VIGÉSIMO. Que, entre las facultades que la ley le confiere a quien la Constitución dota de la potestad exclusiva para dirigir la investigación, se encuentra también el 
llamado principio de oportunidad. En virtud de él y al tenor de lo dispuesto en el artículo 170 del Código Procesal Penal, los fiscales del Ministerio Público tienen la facultad de no iniciar la persecución penal o de abandonar la ya iniciada cuando se tratare de un hecho que no comprometiere gravemente el interés público, salvas las excepciones que el propio artículo establece. Una vez más, la ley dispone que esta decisión debe ser motivada, y comunicada al juez de garantía, quien lo notificará a los intervinientes, si los hubiere, para luego de un plazo decidir si la deja sin efecto. La norma que se reseña dispone que el juez dejará sin efecto la decisión del fiscal cuando "la víctima manifestare de cualquier modo su interés en el inicio o en la continuación de la persecución penal”. De ese modo, la ley confiere, a la víctima del delito, capacidad para oponerse e impedir el no inicio o abandono de la persecución penal por parte del fiscal que se funda en el principio de oportunidad para así proceder.

Aun en los casos en que el juez de garantía no hubiere ordenado iniciar o continuar con la persecución penal, la víctima tiene todavía, en conformidad a lo dispuesto en los incisos quinto y sexto del artículo 170 del Código Procesal Penal, el derecho de reclamar de las decisiones del fiscal ante las autoridades del Ministerio Público, quienes podrán dejarlas sin efecto.

VIGESIMOPRIMERO. Que, de modo análogo a los casos anteriores, la ley establece otras reglas según las cuales la víctima tiene derecho, ante los superiores jerárquicos del propio Ministerio Público o, en los casos más importantes, ante el tribunal de garantía, a oponerse a las decisiones del fiscal que afectan sus intereses. Así es el caso del derecho que le asiste a recurrir al juez ante la suspensión condicional del procedimiento, según lo dispone el artículo 237 del Código Procesal Penal, o el derecho a ser oída por el tribunal antes de que se decida acerca del sobreseimiento u otra resolución que pusiere término a la causa, según lo dispone el artículo 109.

VIGESIMOSEGUNDO. Que, también de modo análogo a los casos anteriores, el legislador prevé aquel conflicto de intereses que se puede producir entre un fiscal del Ministerio Público que decide no acusar y el querellante particular que desea hacerlo. En el artículo 258, el Código Procesal Penal otorga al querellante particular el derecho a oponerse a la solicitud de sobreseimiento formulada por el fiscal, recurso que es resuelto por el fiscal regional. Si el fiscal regional ratificare la decisión del fiscal de sobreseer,"el juez podrá disponer que la acusación correspondiente sea formulada por el querellante, quien la habrá de sostener en lo sucesivo en los mismos términos que ese Código lo establece para el Ministerio Público, o bien procederá a decretar el sobreseimiento correspondiente". De ese modo, el querellante particular queda facultado para iniciar propiamente el juicio en contra de la voluntad manifestada por el Ministerio Público y puede obtener así una protección en el ejercicio de su derecho a perseguir la responsabilidad penal por el hecho del que es víctima.

VIGESIMOTERCERO. Que, a diferencia de todos los casos anteriores, en que la ley, de un modo que no es del caso juzgar ahora, otorga ciertos derechos a la víctima cuando 
sus intereses se oponen a la posición del Ministerio Público, y particularmente a una revisión judicial de aquellas decisiones que ponen término a la investigación o impiden el inicio del juicio o su sustanciación, el inciso primero del artículo 230 del Código Procesal Penal dispone que "el fiscal podrá formalizar la investigación cuando considerare oportuno formalizar el procedimiento por medio de la intervención judicial”. La ley no contempla derecho alguno para que la víctima pueda oponerse o reclamar en caso de que el fiscal decida no formalizar la investigación.

V. Análisis de la constitucionalidad de aplicar la norma impugnada al caso sub lite. Del derecho del fiscal a formalizar la investigación cuando lo considere oportuno.

VIGESIMOCUARTO. Que la formalización de la investigación que el precepto impugnado permite al Ministerio Público realizar cuando lo considere oportuno, produce una serie de efectos que, el tenor literal del artículo 233 del Código Procesal Penal, frasea del siguiente modo:

a) Suspenderá el curso de la prescripción de la acción penal en conformidad a lo dispuesto en el artículo 96 del Código Penal;

b) Comenzará a correr el plazo previsto en el artículo 247,y

c) El ministerio público perderá la facultad de archivar provisionalmente el procedimiento".

VIGESIMOQUINTO. Que, en esas condiciones, si el Ministerio Público no estimare oportuno formalizar la investigación ni concluirla por alguno de los restantes modos que la ley contempla, hasta una fecha posterior a la de la prescripción del ilícito, se arrogaría para sí el privilegio de decidir, sin necesidad de fundar y sin control alguno, la pertinencia de perseguir los delitos que quisiera.

VIGESIMOSEXTO. Que la declaración de inaplicabilidad del precepto legal impugnado obligaría a que la presente causa continúe su curso, sin que pueda tener aplicación lo que en él se dispone. De ese modo, en caso de declararse inaplicable el precepto, la investigación que se lleva a cabo en la gestión pendiente debiera continuar sin una regla acerca de la oportunidad de la formalización. Sin ese precepto, quedaría igualmente claro, en virtud de disponerlo así el artículo 229 del mismo Código Procesal Penal, que la formalización es un acto del fiscal, sólo que no habría regla alguna acerca de la oportunidad en que puede o debe realizarse.

VIGESIMOSÉPTIMO. Que en virtud de la inaplicabilidad de la norma impugnada, y por aplicación directa de la Carta Fundamental, no podría colegirse que el querellante pudiera forzar la formalización, que es lo que persigue el requirente de autos, pues a ello se opondría la regla constitucional que establece que toca al Ministerio Público dirigir de modo exclusivo la investigación. En efecto, la formalización de la investigación es, a no dudarlo, un acto que cambia las condiciones en las que el fiscal realiza su actividad investigativa. Desde luego, la formalización lo habilita para pedir diligencias 
que le están vedadas en la etapa desformalizada de la misma, pero, a un tiempo, somete su actividad a obligaciones que antes no tenía, incluyendo la de concluirla en un plazo máximo de dos años. En esas condiciones, no es posible entender que, inaplicándose el artículo 230 del Código Procesal Penal y por aplicación directa de la Constitución, la víctima quede en condiciones de obligar, cuando ella lo estime oportuno y cualesquiera sean sus fundamentos, a quien la Carta Fundamental confiere la potestad exclusiva de dirigir la investigación, a realizar un acto tan estrechamente ligado con tal dirección como es la formalización de la misma.

VIGESIMOOCTAVO. Que en virtud de la inaplicabilidad de la norma impugnada, y por aplicación directa de la Carta Fundamental, no podría tampoco entenderse que el juez adquiera la facultad de decidir el conflicto entre el Ministerio Público, que no quiere formalizar, y la víctima que quiere que ello ocurra. La inaplicación de lo dispuesto en el artículo 230 cuestionado no haría nacer una norma legal que otorgue una facultad al juez de garantía que éste no tiene y que, al no haberle sido conferida por el legislador, no puede arrogarse, ni aun en virtud de las especiales circunstancias que rodean el caso, a la luz del claro principio establecido en los artículos $6^{\circ}$ y $7^{\circ}$ de la Carta Fundamental, que sancionan con nulidad el ejercicio de atribuciones no conferidas por la Constitución o las leyes.

VIGESIMONOVENO. Que aunque el legislador permitió a la víctima del delito recurrir al juez de garantía para resolver el conflicto de intereses entre ella y el Ministerio Público cada vez que éste adopta una decisión que pone fin a la investigación y, con ello, a las pretensiones punitivas de la víctima, no hizo otro tanto en el caso que éste pusiera fin a esas pretensiones por la vía de su inactividad. Fundado en la idea de que donde hay la misma razón debe existir una misma disposición, se podría argumentar que estamos frente a un vacío del legislador, pero ello no permite llenarlo, en una materia como ésta, por la vía analógica, pues ello vulneraría las normas constitucionales anotadas en el considerando anterior.

TRIGESIMO. Que, como puede apreciarse de lo razonado en los considerandos reunidos en el presente apartado, efectivamente podría producirse en la presente causa un resultado contrario a la Constitución, si es que la decisión de no formalizar del Ministerio Público, sin que tampoco decida sobreseer la misma o ponerle término de algún modo, se prolongare en el tiempo -incluso hasta la fecha de prescripción del delito-, pues ello implicaría desproteger y hacer ineficaz el derecho a la acción que tiene el requirente, en cuanto alega ser víctima de un delito. A un mismo tiempo, debe concluirse que ese resultado contrario a la Carta Fundamental no se corrige en virtud de la inaplicación del precepto impugnado. Ello ocurre porque el efecto contrario a la Carta Fundamental que puede producirse en el caso sub lite no se verifica en virtud de la aplicación de lo dispuesto en el precepto legal, sino por la ausencia de una norma legal que lo complemente, análoga a las que se describen en el apartado III que antecede, en virtud de la cual la 
víctima pudiera reclamar de esa inactividad ante el juez de garantía, con la consiguiente facultad de éste para forzar ese acto cuando lo estimare procedente.

TRIGESIMOPRIMERO. Que, como consecuencia de lo que se viene razonando, estos previnientes estiman que no es posible acoger sin más la acción de inaplicabilidad impetrada, en cuanto ella se dirige a obtener la declaración de inaplicabilidad por inconstitucionalidad del precepto legal impugnado. Tal declaración no sólo no ayudaría a salvar el resultado contrario a la Constitución que amenaza al requirente en la presente causa, sino que sería improcedente, por cuanto no es la aplicación del precepto legal lo que arriesga el resultado contrario a la Constitución, sino la carencia de otra norma legal, que permitiera que un tercero imparcial resolviera el conflicto de intereses entre la víctima y el Ministerio Público que se viene analizando.

TRIGESIMOSEGUNDO. Que la contravención a la Constitución que se viene anotando podría conjurarse en caso que se entendiera que el artículo 186 del Código Procesal Penal entrega no sólo al imputado, sino también a la víctima la facultad de provocar que el juez de garantía fije al fiscal un plazo para formalizar la investigación. Ese precepto legal dispone:

"Artículo 186. Control judicial anterior a la formalización de la investigación. Cualquier persona que se considerare afectada por una investigación que no se hubiere formalizado judicialmente, podrá pedir al juez de garantía que le ordene al fiscal informar acerca de los hechos que fueren objeto de ella. También podrá el juez fijarle un plazo para que formalice la investigación".

En la especie, el requirente invocó ese precepto. Sin embargo, la Corte de Apelaciones de Rancagua, siguiendo en esto a la mayor parte de la doctrina nacional, rechazó tal pretensión con fecha 4 de enero de 2007, entendiendo que las personas afectadas por una investigación son aquellas a quienes el Ministerio Público investiga como posibles responsables de hechos delictuales y no a las víctimas de los delitos.

TRIGESIMOTERCERO. Que no habiendo la parte requirente dirigido su acción de inaplicabilidad en contra del artículo 186 del Código Procesal Penal, esta Magistratura está, a juicio de estos previnientes, vedada de razonar si alguna inteligencia del mismo, unida a lo dispuesto en el artículo 230 del Código Procesal Penal, pudiera evitar efectos contrarios a la Constitución.

TRIGESIMOCUARTO. Que, en virtud de lo razonado hasta aquí, estos previnientes tampoco concurren a acoger la acción de inaplicabilidad en la forma en que ella fue impetrada. Sin embargo, y teniendo presente únicamente las razones expuestas en este voto, concuerdan con la mayoría del Tribunal que una determinada inteligencia o interpretación de lo dispuesto en el artículo 230 del Código Procesal Penal sí puede producir efectos contrarios a la Constitución.

Tal como se ha razonado en considerandos que anteceden, el artículo 230 del Código Procesal Penal confiere a los fiscales la potestad de formalizar la investigación cuando consideren oportuno formalizar el procedimiento por medio de la intervención 
judicial. Sin embargo, el precepto no otorga a los fiscales el derecho a formalizar si lo estiman conveniente. Si así fuere entendido el precepto y ello permitiere al Ministerio Público, en la causa sub lite, mantener una investigación abierta, pero sin formalizarla ni concluirla por una de las vías legales hasta la fecha de prescripción del delito, ello produciría un efecto contrario a la Carta Fundamental, pues implicaría desconocer el derecho que tiene la víctima a ejercer la acción penal pública y a la (igual) protección de la ley en el ejercicio de ese derecho.

Al mismo tiempo, si el precepto se interpretara y aplicara en la causa entendiendo que la facultad del fiscal para formalizar cuando lo estime conveniente incluye la facultad de postergar arbitrariamente la formalización o el término de la investigación, sin necesidad de tener ni de dar fundamento alguno, ello implicaría conferir a la norma un alcance que contradice la obligación de que la investigación -que dirige exclusivamente el Ministerio Público- reúna los requisitos de racionalidad y justicia que exige la Carta Fundamental. Por su propia naturaleza, la investigación penal es una actividad que debe conducir a un fin, ya sea el de formular cargos en contra de quienes resulten responsables o ya sea el de ponerle fin, por algún otro de los medios legales.

TRIGESIMOQUINTO. Que, por último, estos previnientes estiman del caso dejar constancia de su parecer en el sentido de que la declaración contenida en el fallo, y a la que concurren por las razones expuestas en este voto, vincula al Ministerio Público, pues éste se encuentra obligado, en virtud de lo dispuesto en el artículo $5^{\circ}$ de la Carta Fundamental, a respetar y promover los derechos esenciales que emanan de la naturaleza humana, entre los que se cuenta el de que el requirente de esta causa es titular, es decir, a ejercer la acción penal y a contar, en tal ejercicio, con la protección de la ley.

Eventualmente esta misma declaración podría, si es que se verificare el peligro de infracción que se ha detectado, servir además de base en el ejercicio de los restantes derechos que pueden corresponder al requirente.

Redactó la sentencia el Ministro señor Juan Colombo Campbell y la prevención el Ministro señor Jorge Correa Sutil.

Notifíquese, regístrese y archívese.

ROL 815-07-INA.

\section{Comentario}

La utilización del término acción para intentar explicar la activación del enjuiciamiento criminal es quizá uno de los errores más graves en que puede incurrir un legislador. Es que el término acción -salvo la denominada "acción popular"- tiene claras raíces privatistas referidas a la facultad de solicitar tutela a un derecho o interés que pertenece a la esfera exclusiva de quien acciona, lo que está muy lejos del escenario penal. Si se considera que hoy en día la acción es entendida como un derecho fundamental reconocido en términos generales a todos los individuos para que puedan pedir tutela para sus derechos e intereses legítimos, surge la duda si puede utilizarse también 
este derecho en aquellas situaciones donde no existen tales derechos subjetivos e intereses legítimos, como sucede en el ámbito penal. ¿Es que hay un derecho subjetivo del Ministerio Público a imponer una pena o a pedir que se imponga una pena? Y lo mismo para la víctima de un delito. ¿Tiene un derecho subjetivo a pedir que se imponga una pena a su agresor?

En el derecho español se ha entendido por la mayoría de su doctrina y jurisprudencia, incluida la del Tribunal Constitucional, que el derecho de acción constitucionalmente reconocido (art. 24. 1 CE) incluye la "acción penal". Sin embargo, en los países donde se adaptó el término romano de acción al proceso civil moderno, como en Alemania, han ido paulatinamente optando por no utilizar en el enjuiciamiento criminal el concepto de acción tal como se la entiende en materia procesal civil.

Tanto en España como en Chile se ha utilizado el término acción debido a la peculiaridad de que en ambos sistemas junto con el Ministerio Público los ciudadanos -todos o el ofendido- pueden instar la persecución penal. Pero, como se sabe, ello no es así en otros países donde la activación del proceso penal es resorte exclusivo del Estado. Sin embargo, tanto en España como en Chile, aun cuando los ciudadanos puedan incoar la persecución penal, ello no debe comportar una concepción privatista del proceso penal. El proceso penal sigue siendo un asunto de interés público. Para la tutela de ese interés público se crea un órgano público que tiene el deber de actuar para que se aplique una pena si se comprueba el supuesto fáctico normativo penal. Si la ley permite a los ciudadanos presentar denuncia, querella o acusar, no es porque se entienda que esos ciudadanos están ejerciendo un derecho subjetivo fundamental al proceso penal, sino porque la ley (o la Constitución en nuestro caso) les ha facultado para colaborar o para hacer valer el deber del órgano estatal.

Hay que entender que en el proceso penal la decisión de iniciar la investigación penal -salvo en los delitos de "acción privada"-comporta la asunción de una actividad pública, aun en el caso de que se inicie por denuncia o querella particular. Es que en este último caso no hay tutela de intereses privados en juego. El que se querella no está pidiendo tutela para un interés propio sino que está colaborando o bien supliendo una negligente o arbitraria actuación fiscal en el estatal ejercicio del ius persequendi.

No puede haber de este modo un derecho subjetivo público, de naturaleza constitucional, al ejercicio de la "acción penal”, ni siquiera para la víctima. Los individuos no tienen el derecho de someter a juicio penal a otro ciudadano. En este sentido no veo correcta la posición del Tribunal Constitucional en el voto de mayoría de la sentencia que se comenta, que sostiene que la facultad que tiene el Ministerio Público de formalizar o no la causa, habiendo querella presentada, vulnera el derecho de acción de la víctima reconocido en el artículo $19 \mathrm{~N}^{\circ} 3$ en concordancia con el 83 CPR (considerando Cuarto del fallo, y considerandos Quinto a Décimo de la prevención de los Ministros Bertelsen, Correa y Fernández, Francisco).

Ahora bien, si se afirma que las víctimas no tienen un derecho constitucional de acción en materia penal, surge la duda de cómo interpretar el artículo 83 inc. $2^{\circ}$ de la Constitución que establece que "el ofendido por el delito y las demás personas que determine la ley podrán ejercer igualmente la acción penal”. En primer lugar se debe 
dilucidar qué se entiende por ejercer la acción penal en nuestro enjuiciamiento criminal. Si se examina el artículo 83 inc. $1^{\circ}$ de la Constitución, se podrá concordar en que de acuerdo al orden en que se establecen los deberes del Ministerio Público, por acción penal habrá de entenderse el poder para llevar a juicio penal al imputado, es decir, en la terminología del Código Procesal Penal, "acusar" al imputado (art. 259 CPP). Pues si el primer deber del Ministerio Público es investigar y si la investigación se puede iniciar de oficio por este órgano o por denuncia o querella, y luego, si corresponde, el Ministerio Público debe ejercer la acción penal, según reza el artículo 83 inc. $1^{\circ} \mathrm{CPR}$, es lógico concluir que es en este sentido de acusar como se está utilizando la voz "acción penal”. De este mismo modo el Mensaje del Ejecutivo por el que se inició la reforma constitucional que incorporó el Ministerio Público a la Primera Norma establecía como competencia de este órgano "sustentar la acusación penal ante los tribunales".

Sin embargo, si se observa el Código Procesal Penal, la voz "acción penal” no parece estar reservada a la acusación. Al respecto, el artículo 53 inc. $2^{\circ}$ CPP da a entender que se refiere al inicio del procedimiento. "La acción penal pública para la persecución de todo delito que no esté sometido a regla especial deberá ser ejercida de oficio por el ministerio público. Podrá ser ejercida, además, por las personas que determine la ley”. Esas demás personas son las que pueden denunciar o querellarse. Luego está la situación de los delitos de acción privada cuyo procedimiento sólo puede ser iniciado por la víctima mediante querella (art. 55 CPP). Parece entenderse que la expresión "acción penal” se refiere al inicio del procedimiento penal. Pero sucede que la referencia a la "acción penal" está en el título III del Libro Primero, y el "inicio del procedimiento” está regulado en el Libro II en el Párrafo $2^{\circ}$, por lo que la acción penal no se refiere al inicio del procedimiento o no al menos exclusivamente.

¿Cómo ha de entenderse entonces la expresión "acción penal”? Parece ser que se refiere en el Código a la actividad de persecución de las conductas delictivas, lo que abarcaría todas las actividades necesarias para que se llegue a la sentencia definitiva. De hecho, en el Mensaje del Ejecutivo para incorporar a la Constitución al Ministerio Público se hablaba que este órgano tendría "a su cargo la persecución penal pública”, lo que luego en el Senado se modificó por "ejercer la acción penal pública”. Si es así como se utiliza la voz "acción penal”, los particulares, del tipo que sean, ofendidos o no por el delito, no podrán ejercer nunca la acción penal, puesto que su ejercicio es un deber del Estado que se realiza a través de los órganos de los que se ha dotado. Sólo el Ministerio Público podría ejercer la "acción penal". La víctima sólo podrá iniciar o instar la "acción penal" o la persecución penal que compete al Estado, pero jamás ejercerla ella.

¿Cómo conciliar entonces la expresión "acción penal” del artículo 83 CPR con el Código Procesal Penal? Desde luego por "acción penal” no puede entenderse en el texto constitucional como en el Código del ramo en el sentido de procedimiento penal, porque, como ya se señaló, los ofendidos por el delito jamás podrán ejercerlo. Una alternativa es entender que cuando la Constitución le asegura al ofendido por el delito ejercer igualmente la acción penal, está presuponiendo una actividad que supone la activación de la investigación penal mediante la respectiva querella y luego la posibilidad de acusar. Si 
se le permite a un sujeto acusar, previamente se le debe haber permitido querellarse. A todo ello parece tener derecho la víctima.

Pero tener derecho a querellarse y luego a acusar no quiere decir que se tenga un derecho fundamental de acción en los mismos términos que se da cuando se pide la tutela para un derecho o interés legítimo a un juez civil o laboral. Esa negativa no responde a una cuestión sistemática que diría que el derecho de acción está regulado en el artículo $19 \mathrm{~N}^{\circ} 3$ inciso $1^{\circ} \mathrm{CPR}$ y no en otras disposiciones del texto constitucional, sino a que es inconcebible un derecho de acción en un procedimiento penal público y regido por el principio de oficialidad. El derecho de acción sólo es concebible tratándose de intereses privados o, más en general, donde figure la confrontación de los intereses pretendidos por dos sujetos antagónicamente, lo cual no existe en materia penal.

El artículo 83 CPR debe ser analizado fuera del ámbito del derecho fundamental de acción. Debe significar para el legislador procesal penal la obligación de considerar desde luego a la víctima como parte activadora del deber estatal de perseguir las conductas delictivas. Es decir, el legislador procesal penal se ve en la obligación de considerar a la querella particular como una de las vías de inicio de la persecución penal y la posibilidad del querellante de acusar particularmente, si es que se llega a ese estado. No se trata de un derecho fundamental de acción entendido como el poder para deducir una pretensión ante un tribunal de justicia y obtener una sentencia de ese tribunal, porque ello, en materia procesal penal, sería propio de un sistema radicalmente acusatorio, completamente privatizado, sistema que es incompatible con la existencia de un órgano público que tiene como deber dirigir en forma exclusiva la investigación penal, y en su caso, acusar, como lo consagra el sistema constitucional chileno (art. 83 inc. $1^{\circ} \mathrm{CPR}$ ).

Ni siquiera cuentan con un derecho al proceso penal en tales términos los ciudadanos ingleses, cuyo Estado tiene quizá el sistema procesal penal más privado o "acusatorio puro" del orbe, puesto que en algunos casos las víctimas para llevar a un imputado a un juicio penal requieren de la autorización previa del Estado por parte del AttorneyGeneral o del Director of Public Prosecutions. Sin esa autorización estatal previa, pues, no hay derecho al proceso penal por la víctima.

Todo ello debe llevar a entender que la víctima tiene derecho a participar en la “acción penal", querellándose desde luego, y acusando si la investigación ha llegado a un estado en que es procedente hacerlo, según la dirección de la investigación que ha llevado el órgano estatal persecutor.

Del entramado constitucional chileno queda claro entonces que la víctima tiene derecho a presentar querella. Ese derecho podrá ser considerado fundamental pero no en los términos del derecho de acción que asegura al actor la iniciación del proceso y una respuesta del tribunal, porque en este caso no es un derecho autónomo, sino que está condicionado a lo que realice el órgano estatal obligado a llevar a cabo la persecución penal; el Ministerio Público. Todo ello indica que las víctimas no tienen derecho a un juicio oral y público en nuestro ordenamiento jurídico. Pare ello se requeriría modificar la Constitución y crear derechamente un sistema de enjuiciamiento criminal "acusatorio puro”, como se conoció en épocas de la República en Roma. Significaría, en otras 
palabras, convertir la persecución penal pública en privada, lo cual no se condice con nuestro texto constitucional vigente.

La introducción del Ministerio Público a la Constitución de 1980 comportó una decisión política de compromiso entre un modelo presentado originalmente por el Ejecutivo, en que la persecución penal destacaba por su clara preeminencia pública y oficial, y las modificaciones introducidas por el legislador que buscaron una mayor participación de la víctima en el enjuiciamiento criminal. Ese resultado transaccional debe comportar alejar toda concepción exclusivamente estatal, pública y oficial del enjuiciamiento criminal, así como una concepción privatista o acusatoria pura del mismo. Ese modelo se resume en participación por parte de la víctima en la actividad persecutoria penal que debe llevar adelante el Ministerio Público. Pero participación no es lo mismo que titularidad del enjuiciamiento criminal. A eso no hay derecho en nuestra Constitución.

Cosa distinta es si el legislador dispusiera que la única vía para presentar las pretensiones civiles que se derivan del delito sea ante el juez penal luego de formalizarse la investigación. En ese caso para que el derecho de acción de la víctima fuera tutelado, no podría depender del poder discrecional del Ministerio Público formalizar o no la investigación. En un caso así el legislador debería establecer como trámite obligatorio del procedimiento, una vez presentada la querella, la etapa de formalización de la investigación. Es que en este caso esos ciudadanos tienen derecho a una tutela de sus derechos e intereses privados, es decir, tienen derecho a deducir una pretensión civil y a obtener una respuesta por parte del órgano jurisdiccional, aunque el ejercicio de dicha pretensión figure inserta dentro de las actividades del enjuiciamiento criminal.

Pero como sabemos, la víctima por delito en nuestro sistema jurídico puede deducir su pretensión civil ante los juzgados penales o ante los civiles, según su libre elección, por lo que el problema hipotético aquí planteado no puede presentarse.

En definitiva, las víctimas por delito tienen siempre derecho a deducir una pretensión civil y a obtener una respuesta judicial a esa pretensión. Sin embargo, si además de la tutela de sus derechos e intereses civiles desean que se le aplique una pena al supuesto agresor penal, necesitarán que el Ministerio Público decida formalizar y llevar a juicio a este sujeto.

Está bien quizá que las víctimas de delito reclamen en las calles y en los medios de comunicación venganza bajo el título de "que se haga justicia", pero el Derecho como sistema normativo racional no puede caer en esa trampa. Y menos el custodio de la Constitución. 